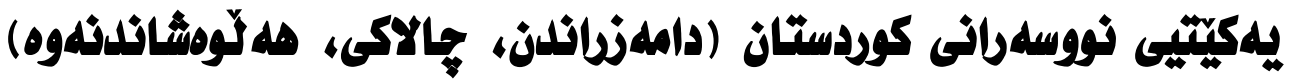

دلشّاد علدى محلمهد

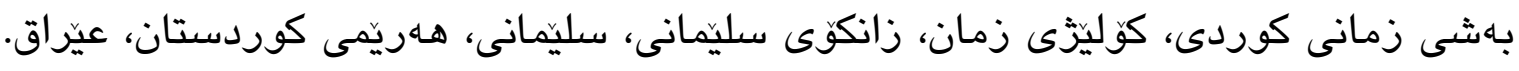
dr.dilshad52@gmail.com : بيمهيل:

\section{ثلهوزاد علهى ثئه حمهد}

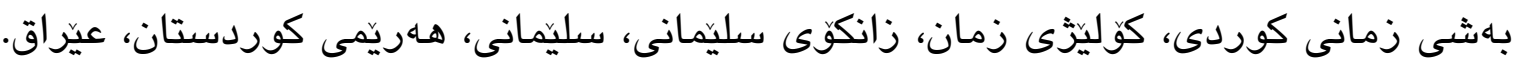

ئيمهيل: Nawzad.ali@hotmail.com

\section{هيوختג:}

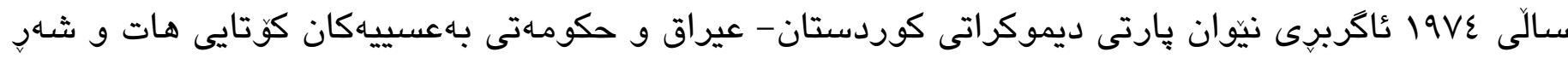

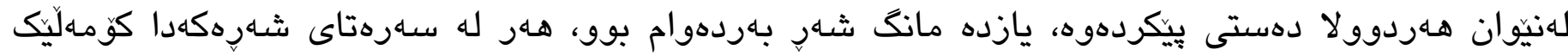

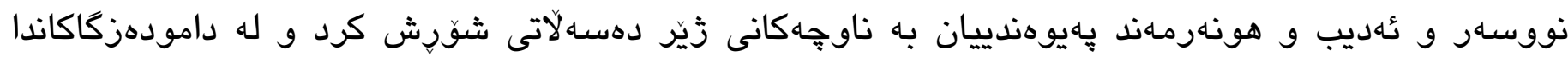

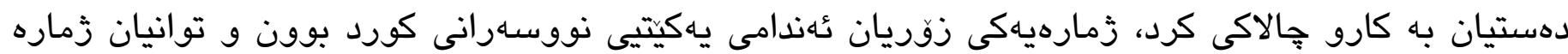

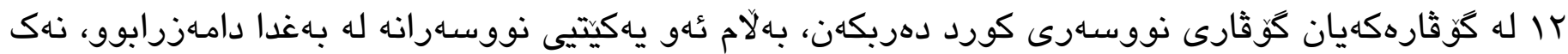

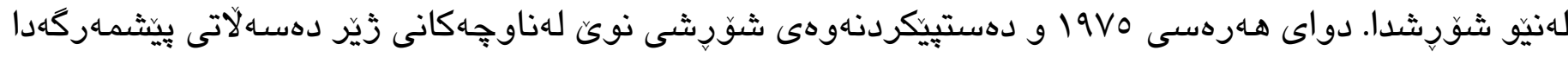

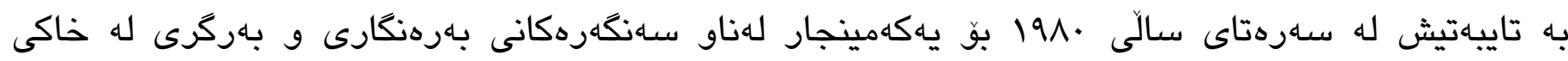
كوردستاندا ريكخراويكى تايبهت به نووسهر و ئهديبان دامهزرا و ناوى لينرا يهكيتيى نووساهرانى كوردستان. لهم تويزّينهوهيهدا هـلَوهسته لهسهر دامهزراندن و كارو جالاكييهكانى يهكيتيى نووسهرانى كوردستان كراوه،

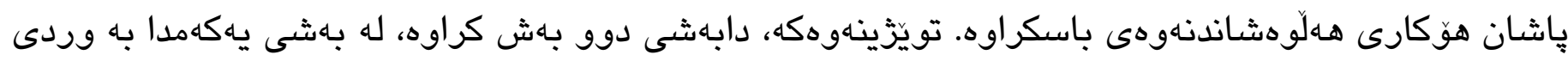

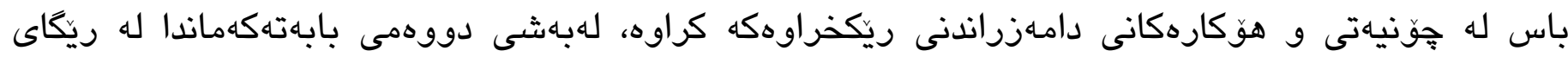

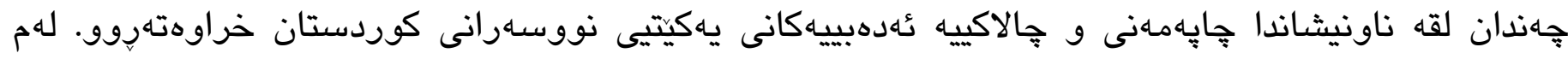

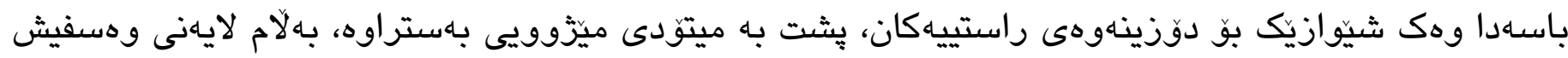

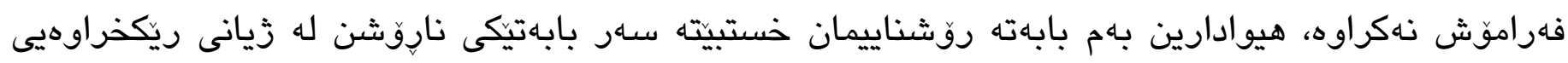
• بيشـاهيى له كوردستاندا.

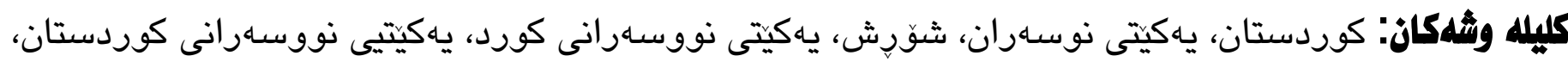
كُوار، كتيب، ئهدهبى بهرهنكارى. 


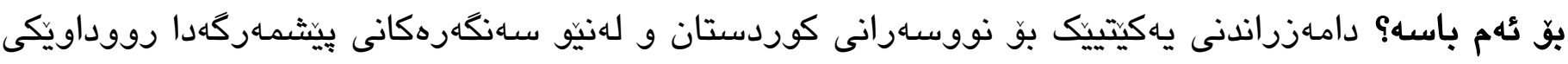

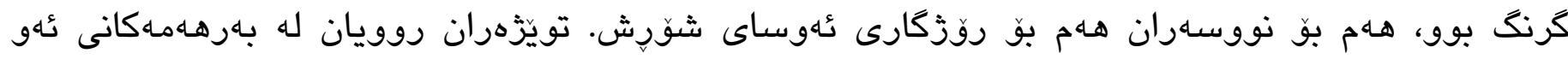

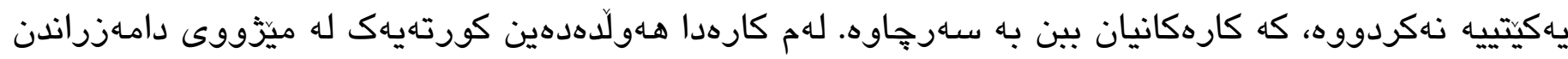
و كاروجالاكييهكانى يهكيتيى نووسهرانى كوردستان باس بكانهين.

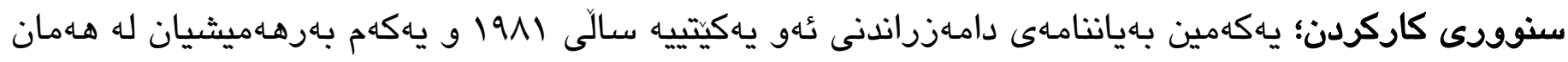

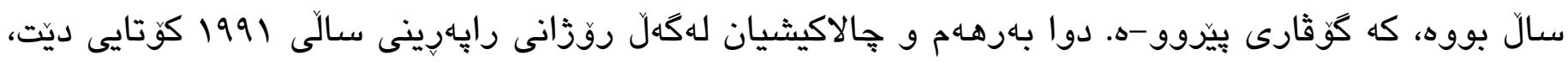

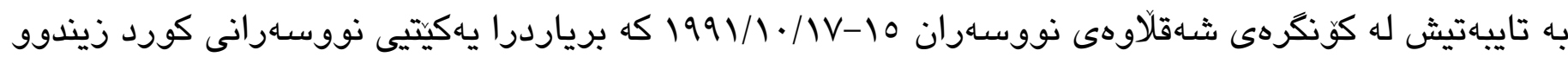

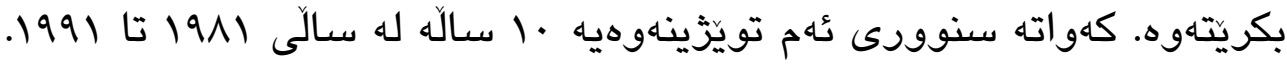

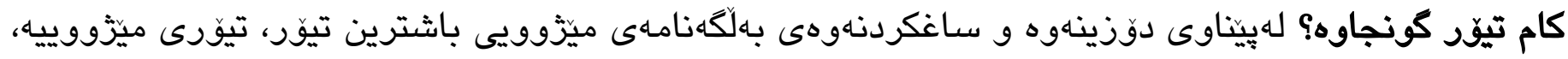

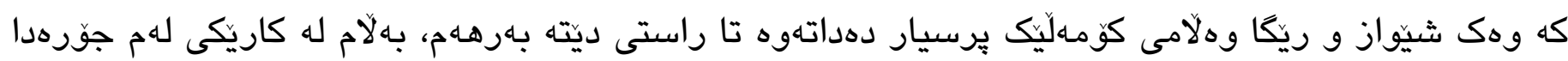

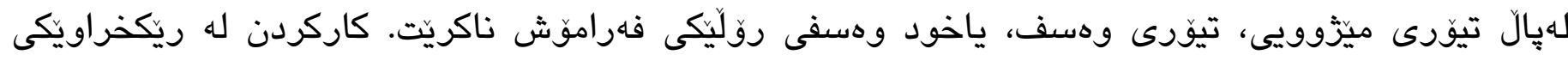

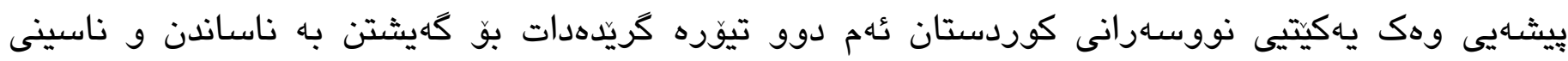

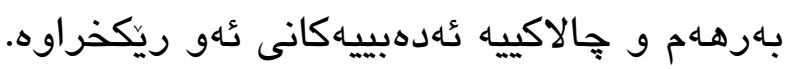

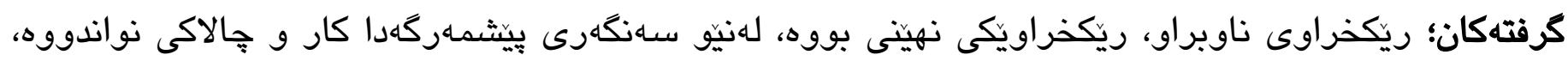

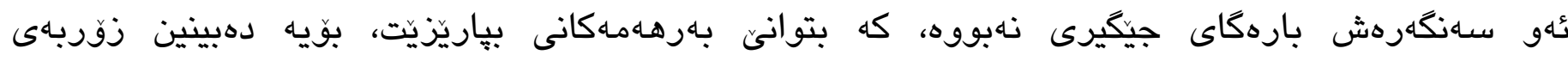

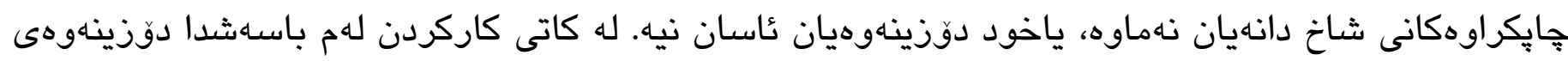

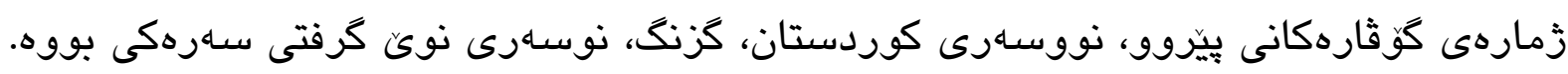

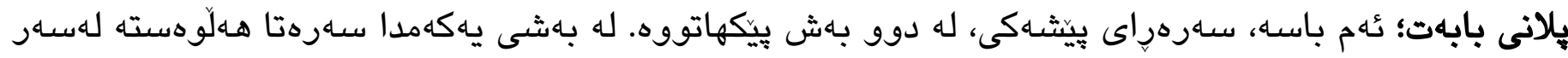

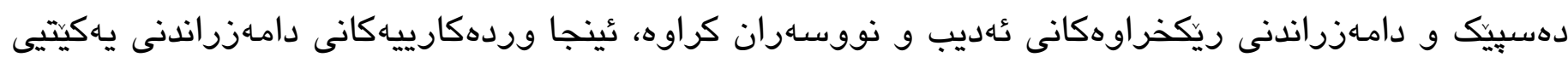

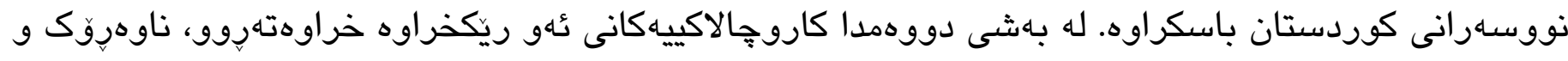

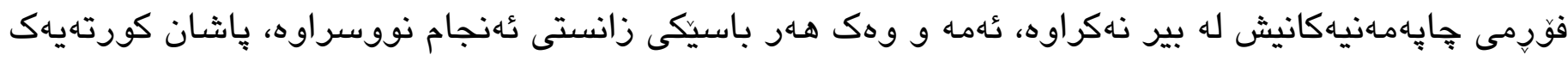

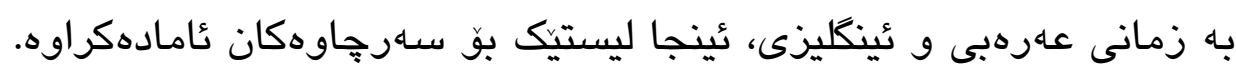




\section{بلأشى يلمكلم}

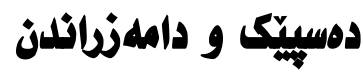

\section{دمستيكيك و يلهكيتى ثووسلهرانى كورد}

له بيستهكانى سـادهى رابردوودا، نووسـار و روشنبيرانى كورد هـولِيانداوه دهسته، يانه، ريّكخراوى تايبهت بـ

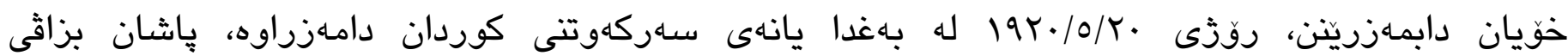

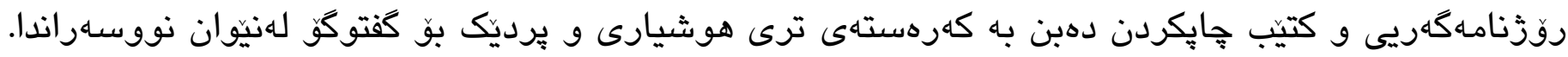

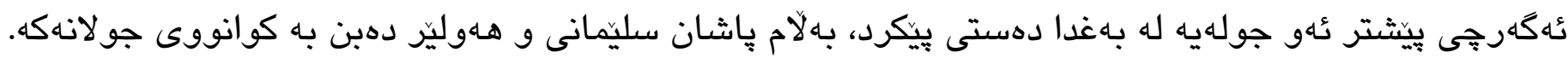
وهك دهستيّك بو بيركردناهوه له دامهزراندنى رينكخراويّكى تايبهت به ئهديب و نووسـهارانى كورد، ديلانى ثـاعير دهنووسيتي(ديلان، مارس و حزيران 901 (1) ل) بابهتى كوبوونهوهى نووسـار و شاعيرانى كورد بوّ باسكردن له

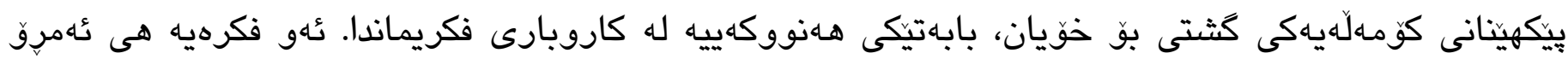

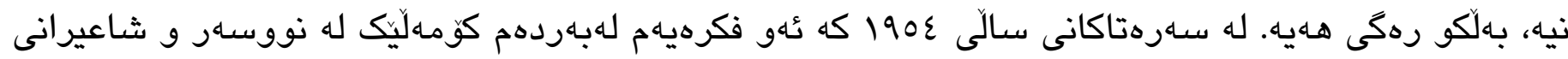
كورد له شارى سليّمانى خستهروو به حهماسهتهوه وهركيرا و وهك هـنكاوى يهكهم له قهلّم درا و جههند

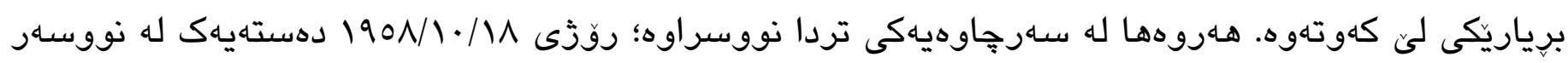

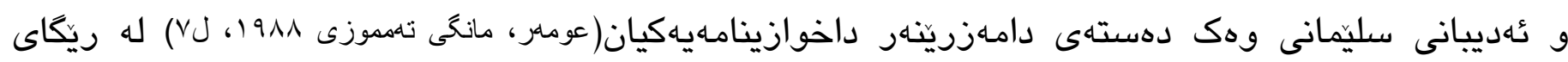

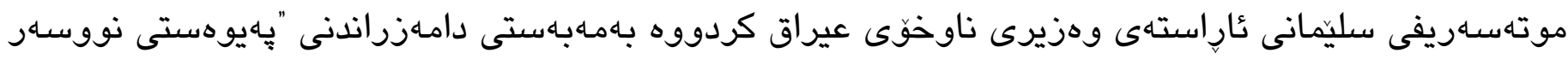

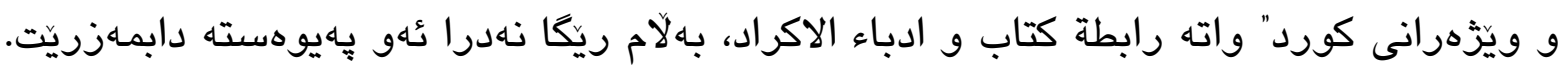

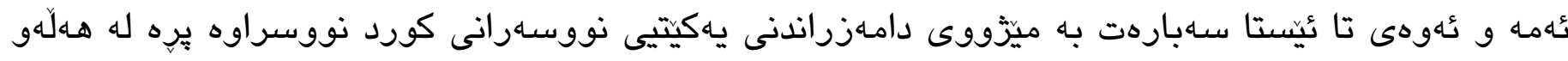

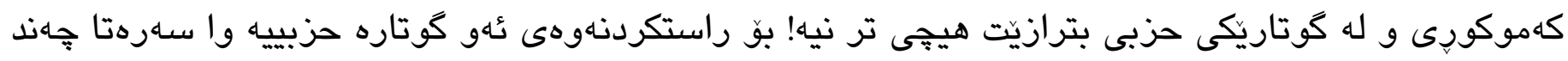

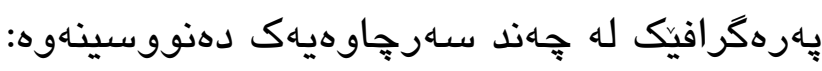

روزّنامهى ئازادى حزبى شيوعى عيراقى كورته يانورامهيهكى هـولهكان دهخاتهروو "ماوهيهكه باس له

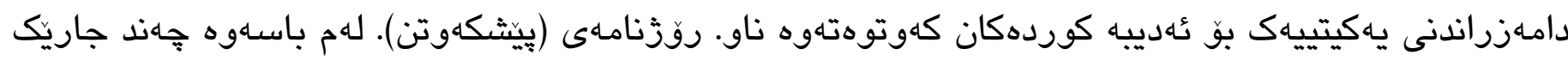

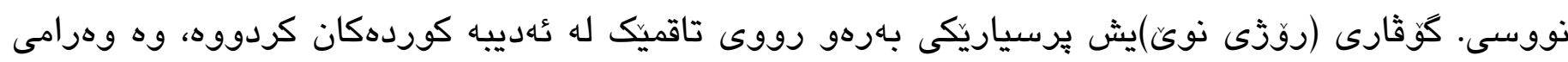

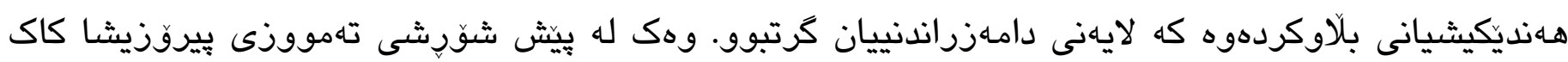

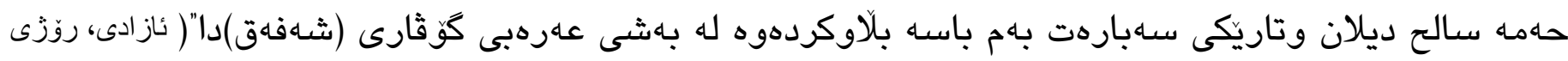

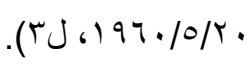

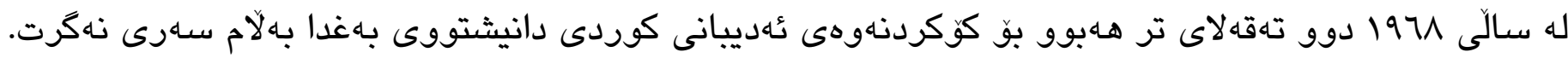

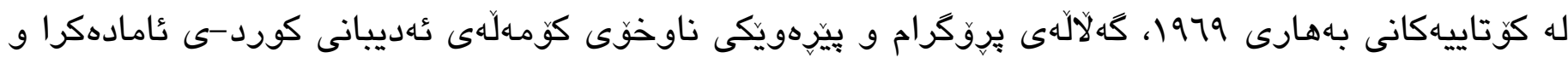

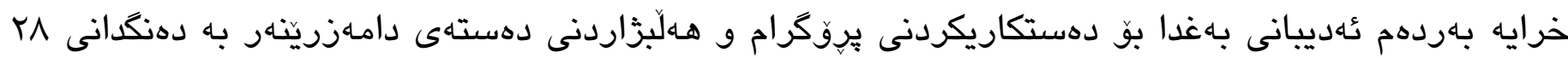


رووناكبيرى كوردى شارهكه ئهم زاتانه بوونه دهستهى دامـزرينّهر: د. مارف خهزنهدار، د. ئيحسان فوئاد، د.نهسرين فهخرى، د.عيزهدين مستهفا رهسول، د.كاميل بهسير و بهريزّان: جهمال عهبدولقادر بابان، حهماهى مـهلا كهريم، حسيَن عارف، نوورى عهلى ئهمين، خاليد دليّر، كاكهم مـهم بوّتانى، له شوينينكى تردا نووسراوه: "به

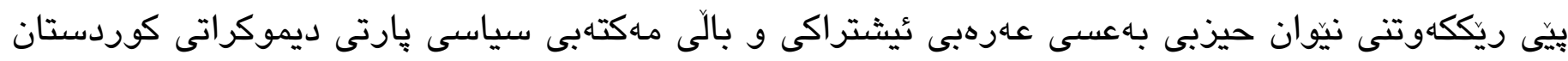
له /979/19 1979 بريارى مافى رووناكبيريى كورد له حكوماهى عيراق دهرجوو. ريَّكى به رووناكبيرانى كورددا،

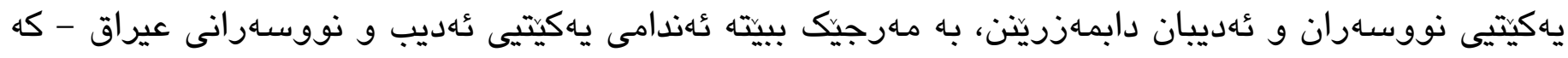

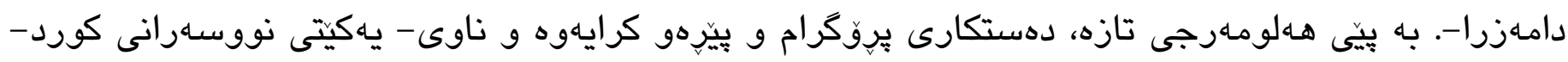

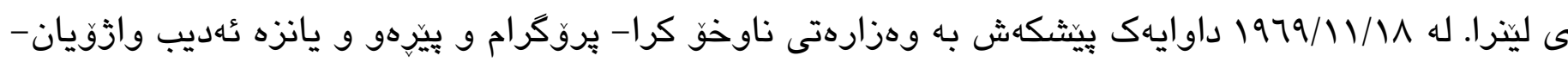

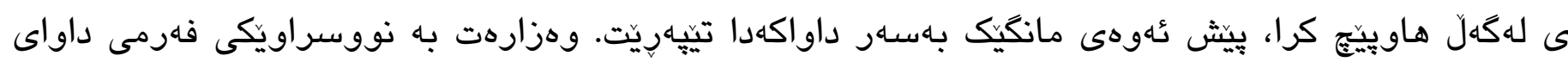

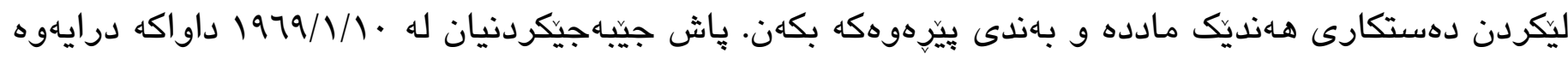

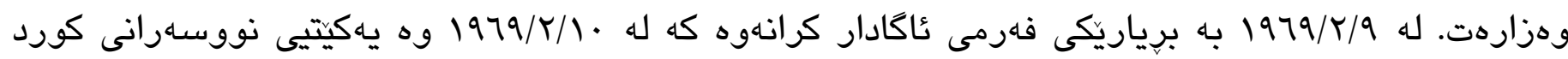

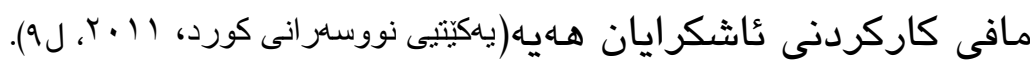

دواى شوّرشى جِواردهى تهمموزى سالى 1901 بواريك رهخسا كه نووسـهر و ئهديبانى عيراق ريكخراوى

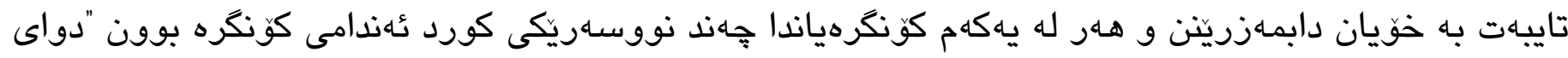

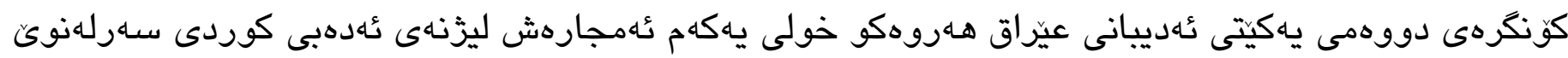

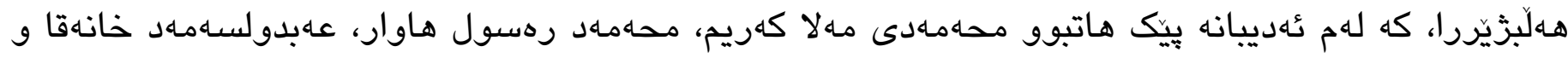

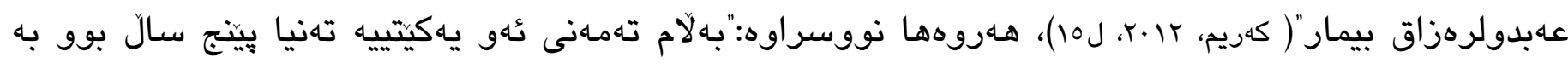

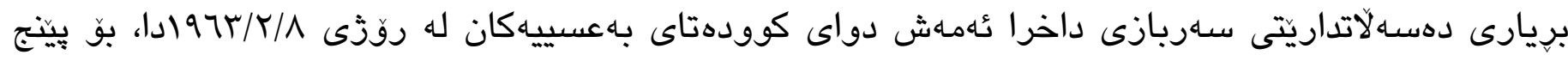
سال ئهديبانى عيراق بحئ ريكخراو مانهوه، تا له سالّى 971 ادا جاريّكى تر ريكخراوهكهيان زياندهوه و ئهمجاره

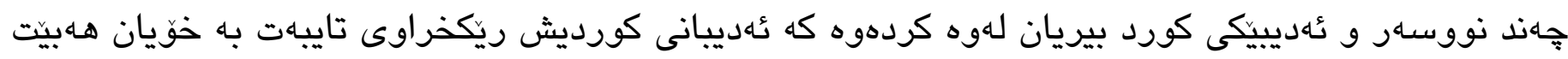

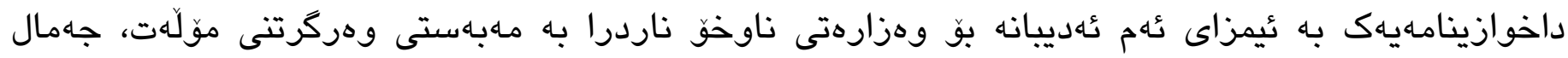
عهبدولقادر بابان، دكتور مارف خهزنهدار، دكتور عيزهددين مستهفا رهسول، دكتّر ئيسسان فوئاد، دكتور نهسرين فهخرى، دكتقر كاوس قهفتان، محهمهدى مـهلا كهريم، كاكهمهم بوّتانى، خاليد دليّر، حسيِن عارف، نورى

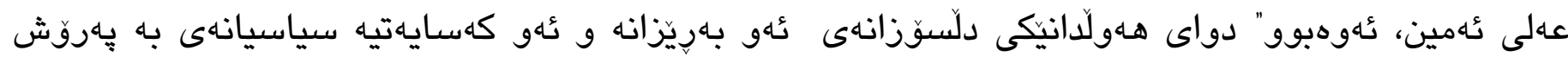

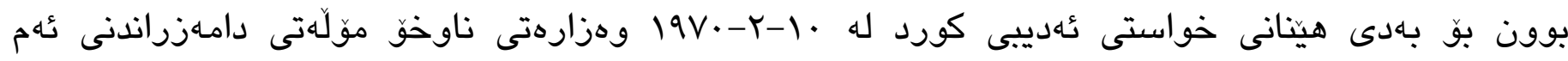

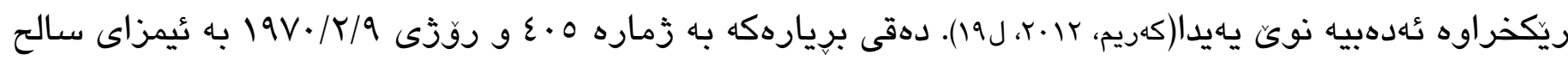
مـهدى عهماش وهزيرى ناوخق دهرجووه.

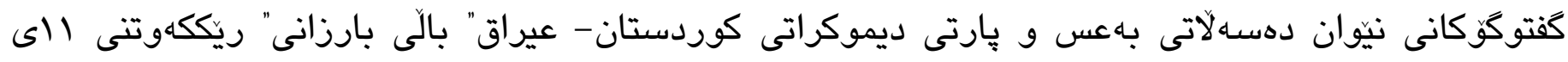

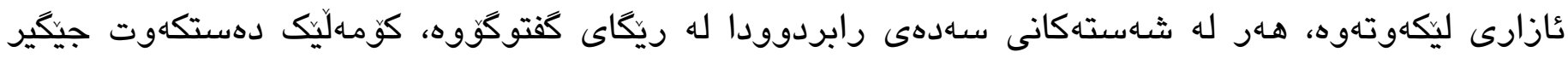




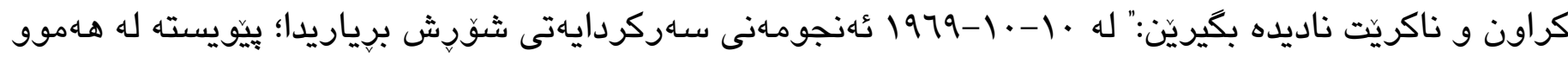

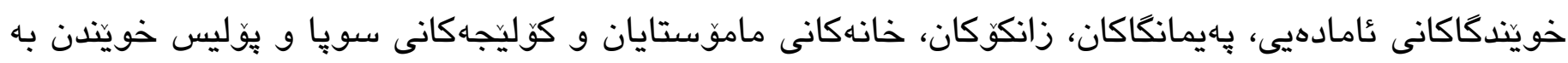
زمانى كوردى بيت، هـهوهها كتيبه زانستى و ئهدهبى و سياسييهكان به زمانى كوردى بن كه كُزارشت له داخوازييه نيشتمانى و نهتهوهييهكانى كهلى كورد بكهن و كئديب و شاعير و نووساهرانى كورد دهتوانن يهكيتيى

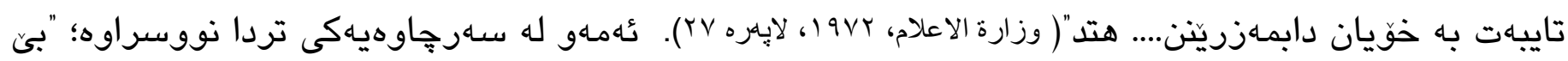

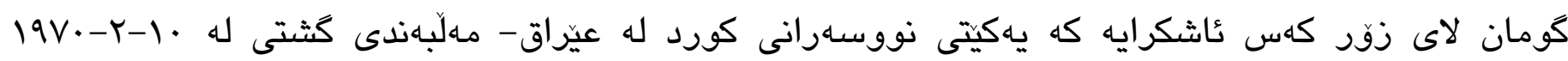

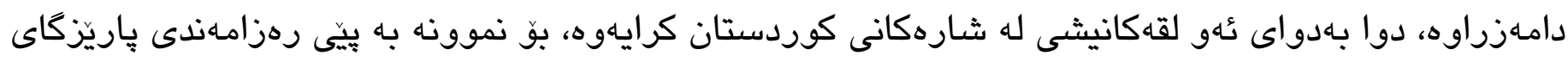
هـاهوليز و به فهرمانى زماره له). بو لقهكانى تريش به هـهان شيّوه. كهواته يهكيتيى نووسـهرانى كورد، يِيش ريّككهوتنى الى ئازار كارى بّ

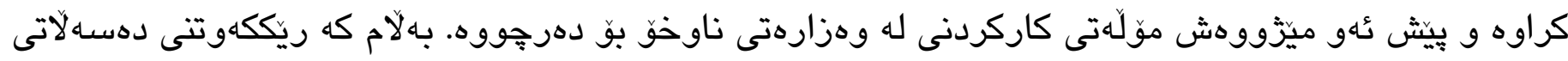

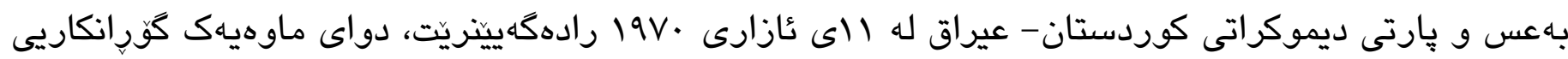

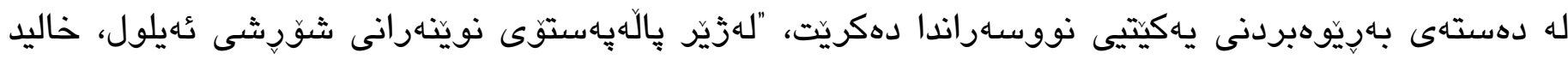
دليّر و كاكهماهم بوّتانى وهلاوهنران، جهمال بابان-يش ئامادهنهبوو له تهك ثئوانى تردا كاربكات و وازى هينا،

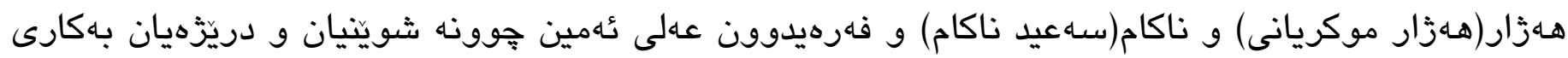

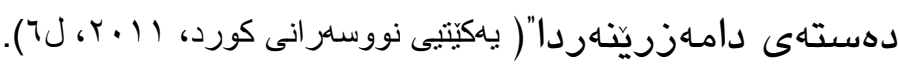

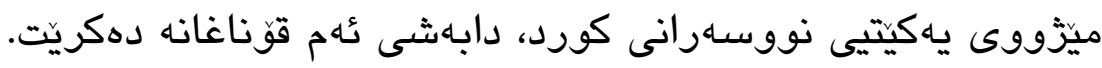

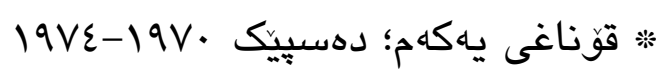

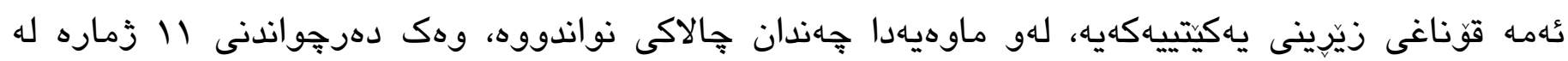
كُوقارى نووسـارى كورد، جِالاكى و بـرنامه له تهلهزيوّن و راديوّدا، هـروهها لقهكانيش خاوهنى دهيان جالاكى تئهدهبى و روشنبيرين. 19V0-19Vع قوّناغى دووهم؛ خهباتى نهينى

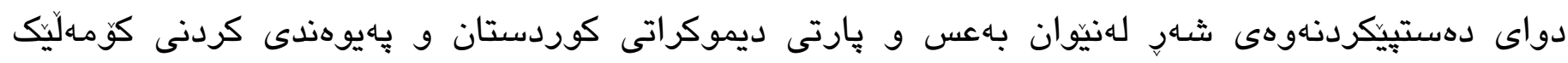

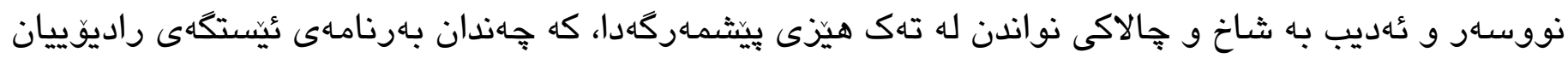

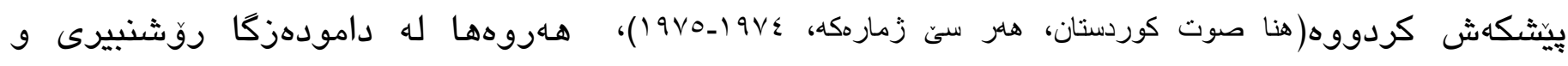

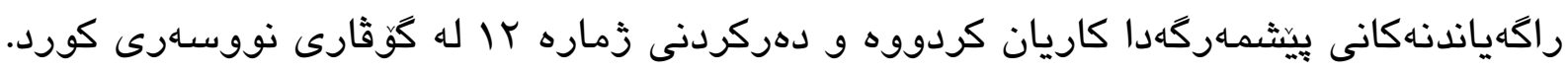

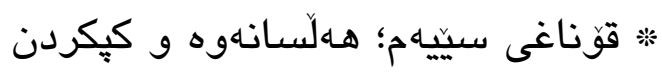




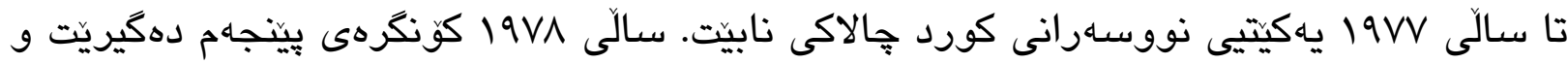

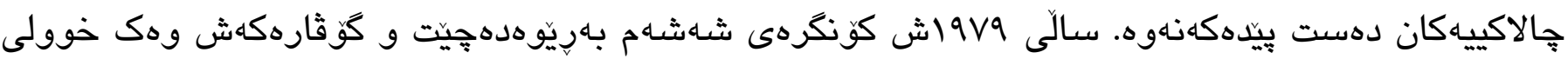
دووهم دهست بـ دهرجوون دهكاتهوه. بهلاّم له سالّى •191 بهاعس بريار دهدات، يهكيتيى نووسـهانى كورد

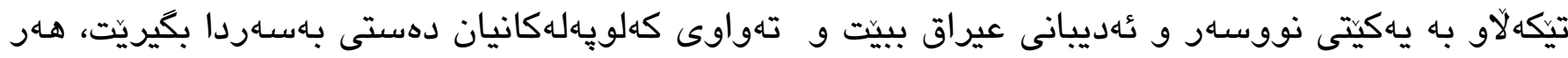

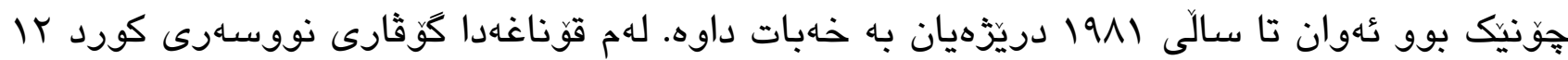

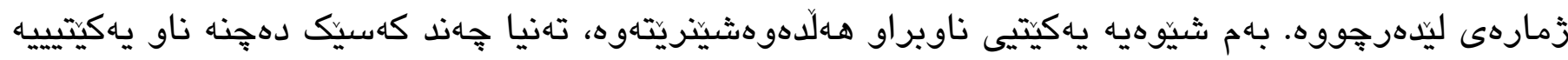

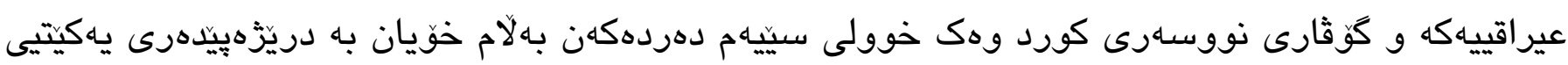
نووسـرانى كورد نازانن(نووسهرى كورد، 1919 1، لب).

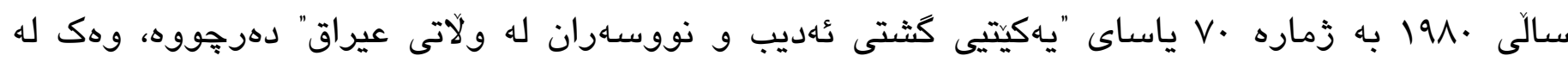

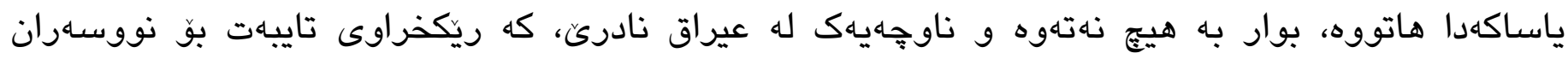
دابمهزرينتن. ئهم ياسـايه كَتوكَّ و نارهزايى ليكهوتهوه، به تايبهتيش له لايهن نووسـهر و ئهديبانى كورد، دواى

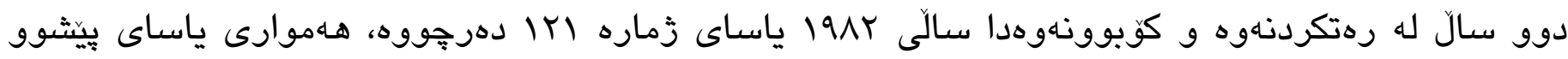

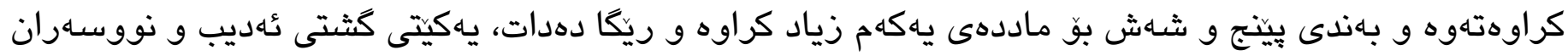

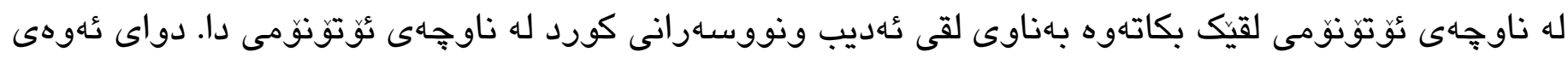
كه ياسايهكه هـهوار كرايهوه، دهركاى يهكيتيى نووسـهرانى كورد داخرا و نهيتوانى جالاكى تر كئنجام

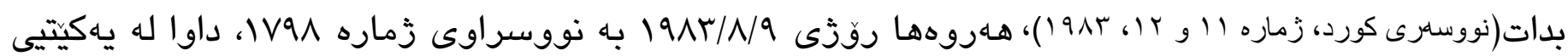

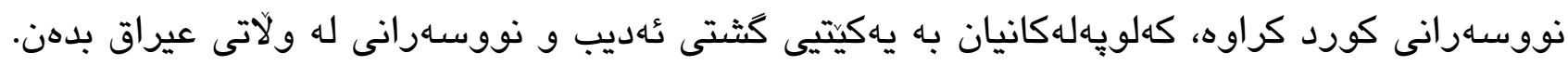

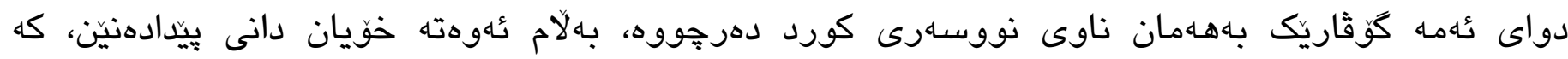

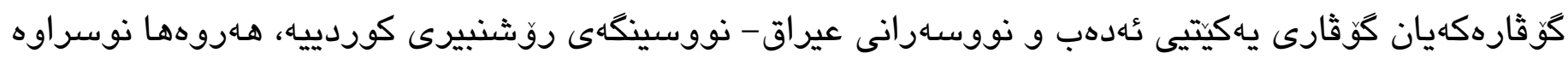

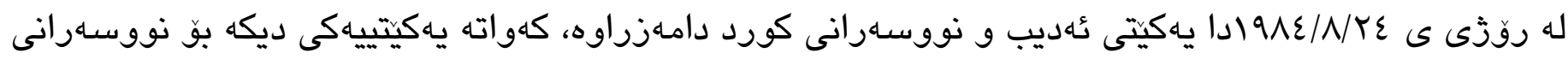

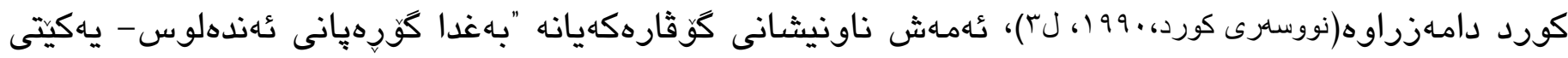

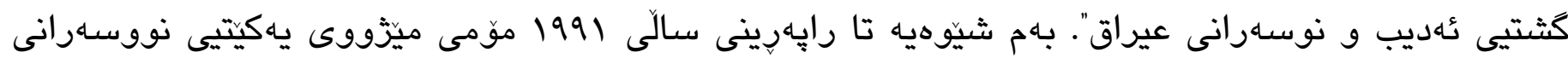

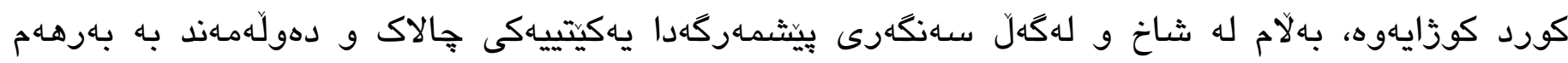
دامـزراوه. 


\section{دامهزراثلفى يلكيتيى ثووسلهرانى كوردستان}

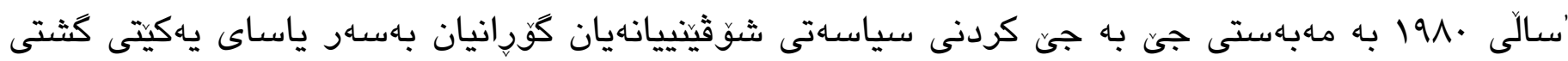

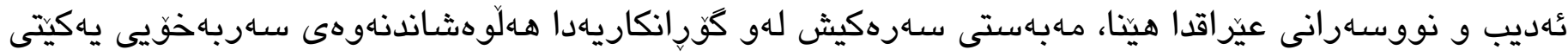

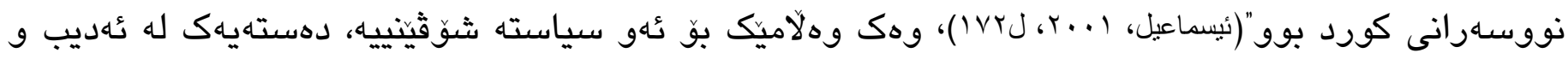

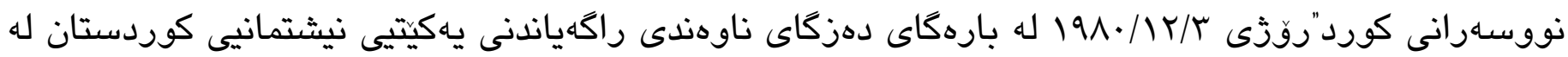
توزهله بانكَهوازيكيان بو نووسهرانى كورد بلاوكردهوه و تيايدا رايانكاياند كه ليزّنهى ثُامادكردنى يهكيتى

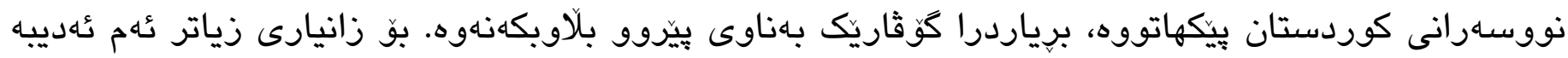

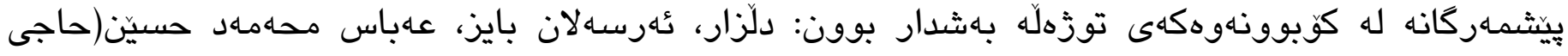

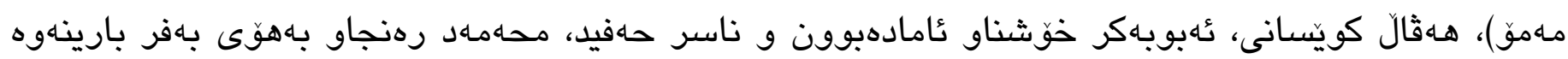
و ثٔهوانى تريش بههوى دوورييان له بارهكاكانى سـهركردايهتى نهيانتوانى بهشدار بن، ئهم بريارانه دران: بيّيك

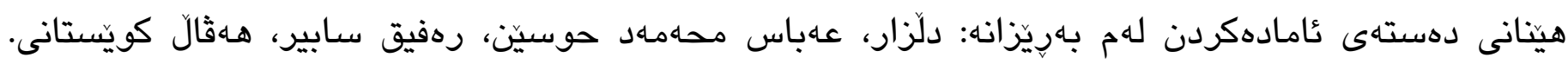

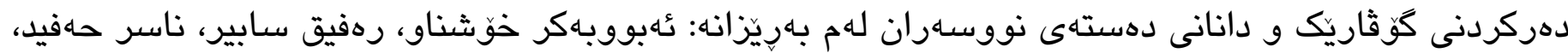

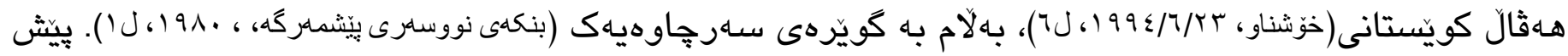
عُهم كوّوونهوهيه كوّوونهوهى تر له دهزكاى ناوهندى راكهياندنى يهكيتيى نيشتمانيى كوردستان كراوه بو

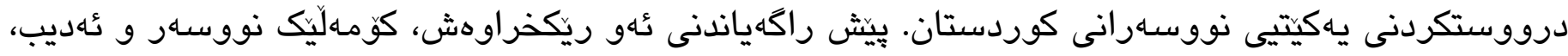

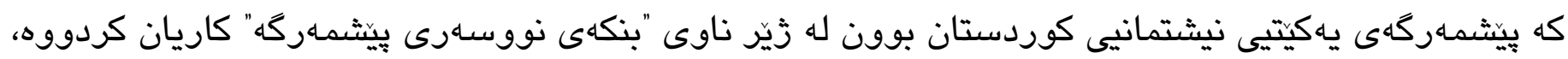
باو ئيمزايه يِيشـكيان بو ناميلكهى جلهى شهاهيدبوونى جهميل رهنجبهر نووسيوه و تيايدا هاتووه: "ئهم جهاند

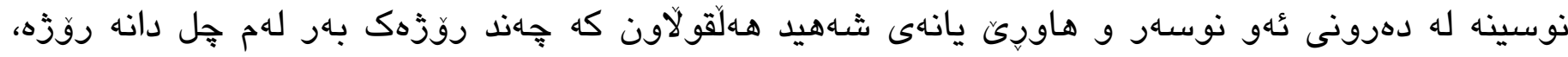

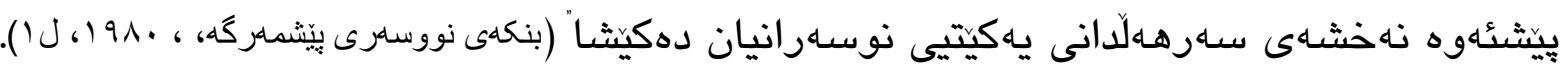

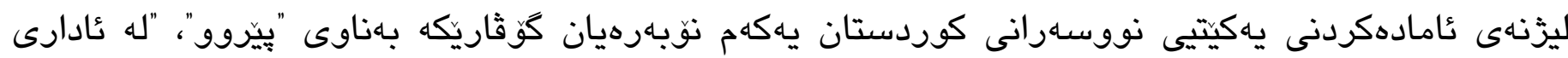

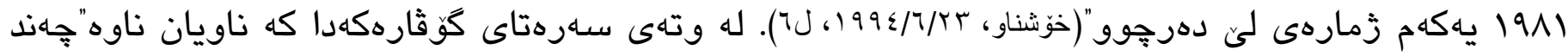

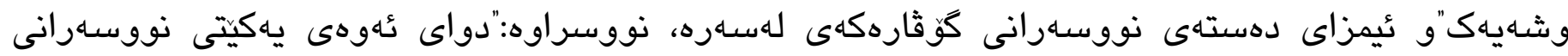

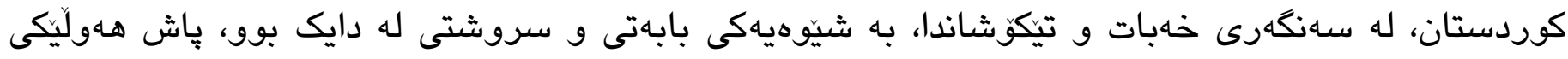

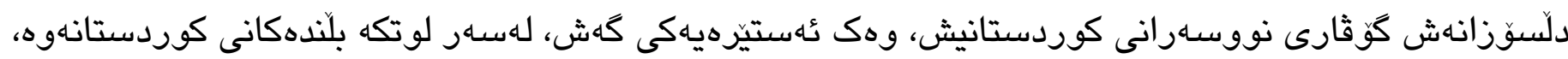

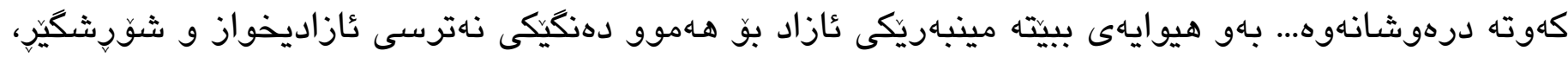

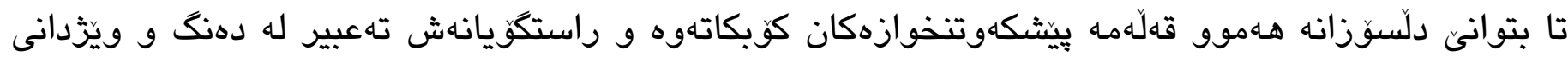
هـاموو ئهو نووسـره كوردستانيانه بكات كه ياراستنى ئهدهب و هونهرى رهسهنى ميللهتهكيان، به ئهركى

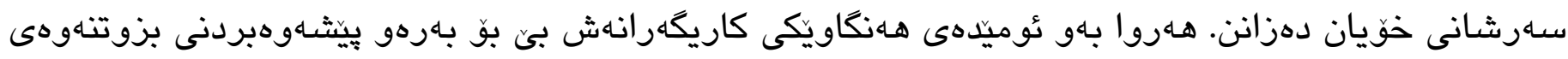

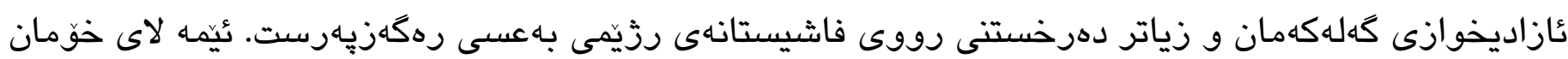




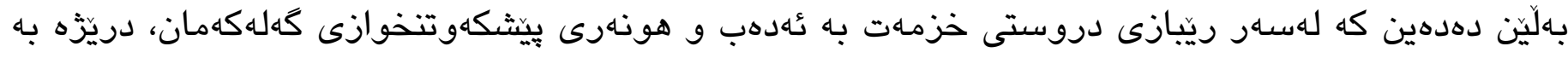

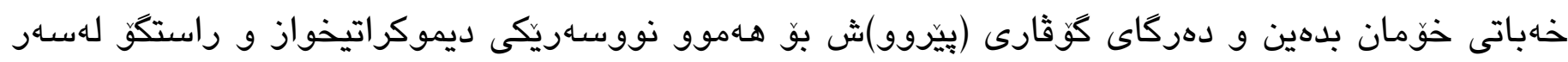

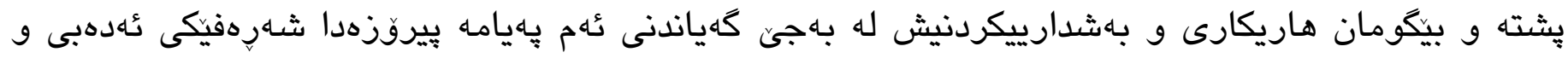

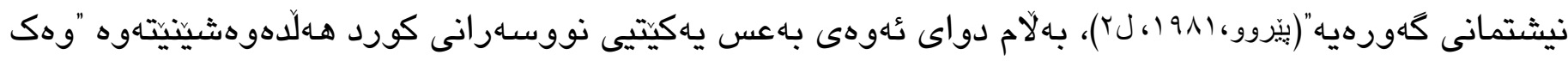

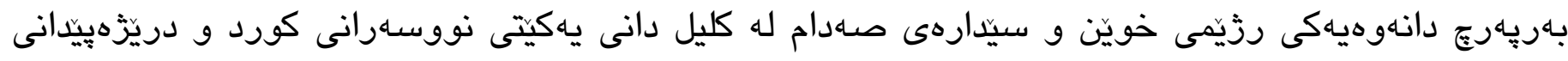

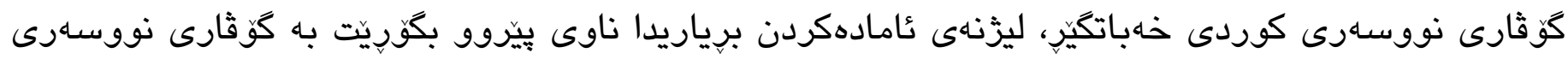
كوردستان ( كه نزيكتره له ناوى يهكيتى نووساهرانى كوردستان-هوه). كُوثارى نووساهى كوردستان خوّى بهدهنكى هـهوو ئهديب و روناكبيرى رايهرين يِيشكاوتخوازى كهلهكهان ئهزانى و بهشهارهف و شانازييهوه

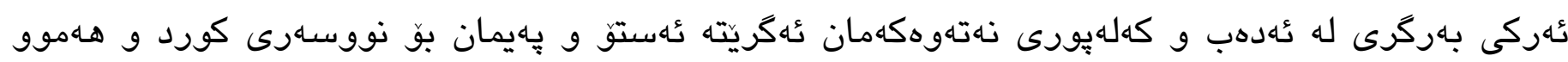

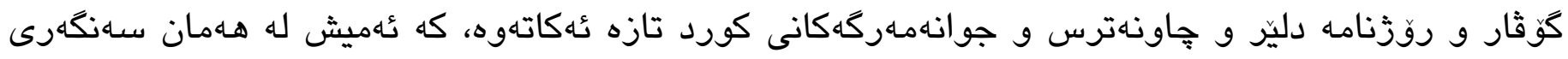

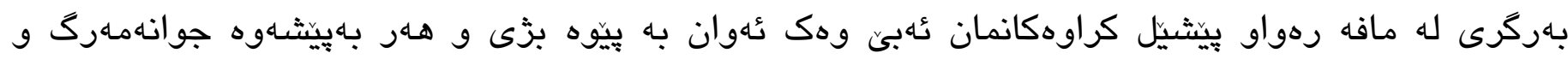

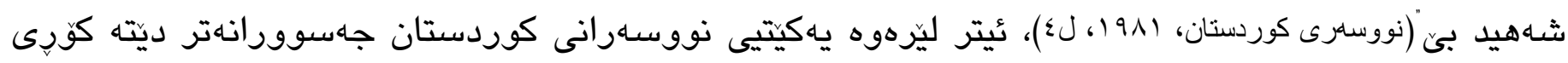
خهبات و يُره به جـالاكييه كانى دهدات.

يهكيتيى نووسـارانى كوردستان له ماوهى ·ل سالدا 1911 تا 1991، يرٍ بهرهـمترين ريكخراوى عُدهبييه، له

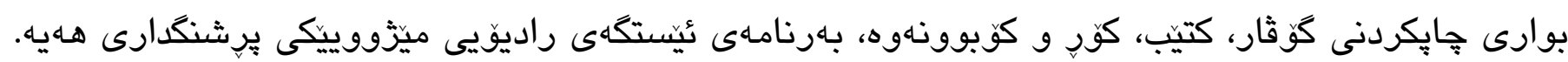

\section{منو}

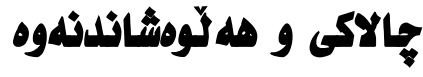

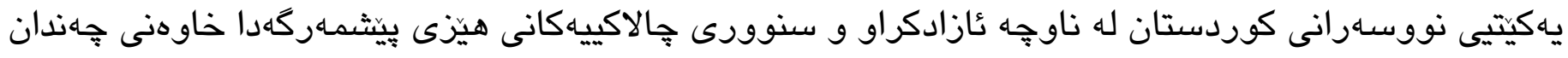
جالاكييه له جهاشنى كور و كوَبوونهوه و بـشداريى له بوّنه كوردستانى و نهتهوهيى و حزبييهكاندا كردووه،

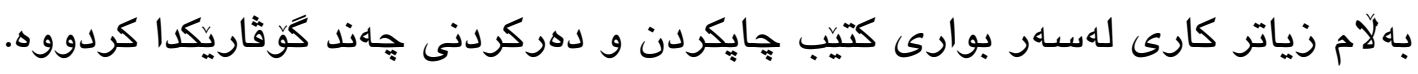

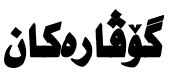

له ماوهى · ا سالَدا يِينج كُّثارى دهركردووه، كه ئهمانهن؛

-1

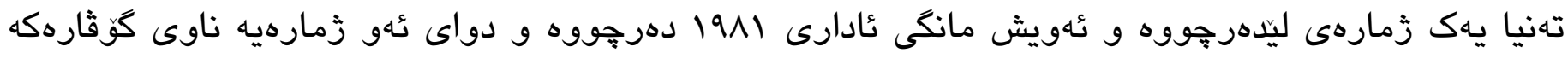
بو نووسـرى كوردستان دهكَّن و له زماره ا دهست به دهرجوون دهكات. ليزّنهى ئامادكردنى يـكيتيى نووسـهارنى كوردستان كَّارى يِّرووى دهركردووه. 


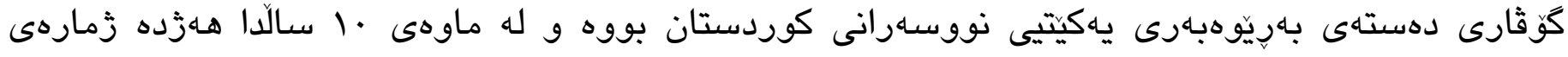

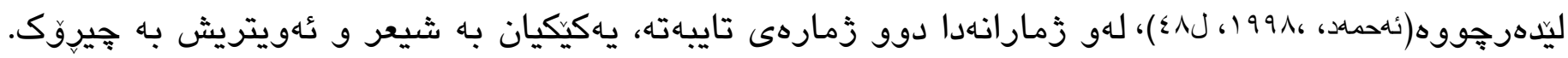

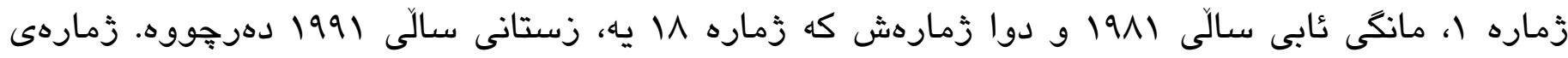

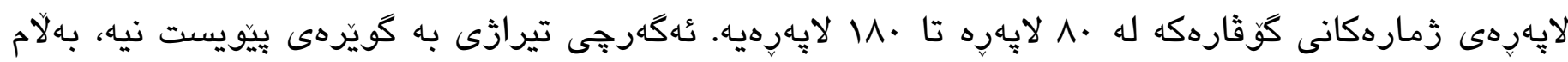

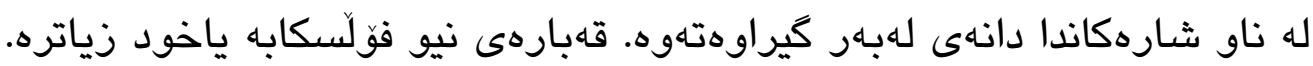

\section{r- r}

كَّثارى يهكيتيى نووساهرانى كوردستان- لقى كهركوك، له شاخ له سالّى r/919 تا 1919 جهوارده زمارهى

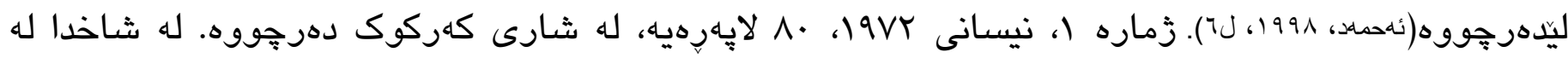

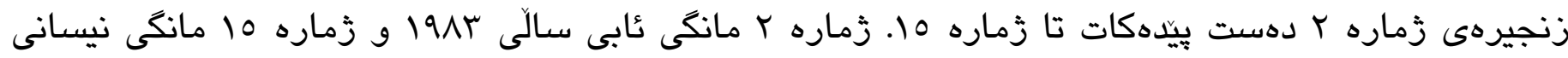

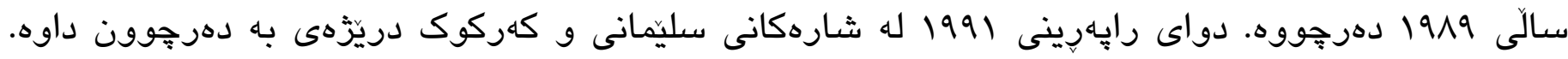

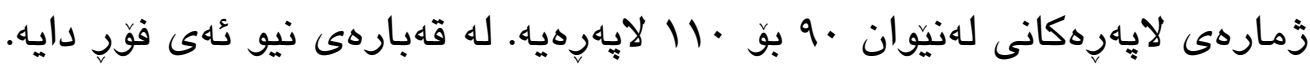

\section{צ- نووسلهرى نوىن}

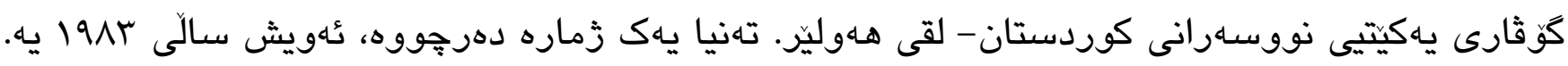

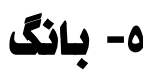

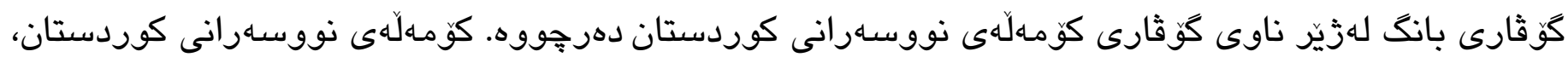

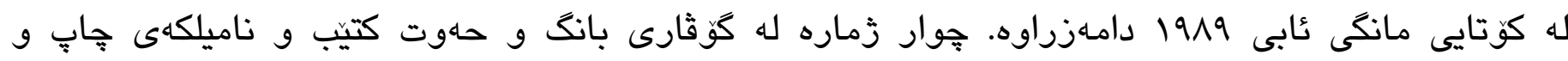

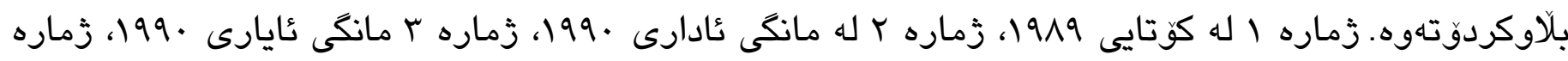

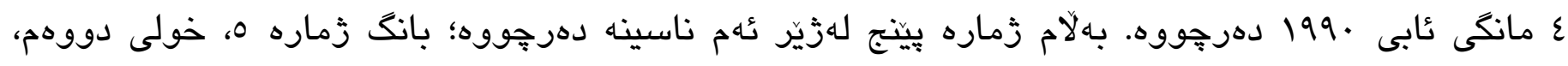

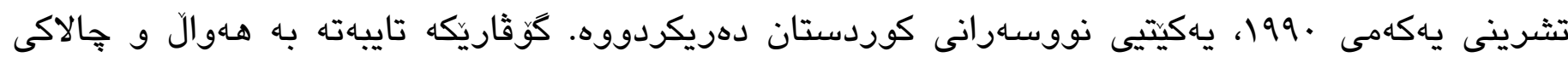

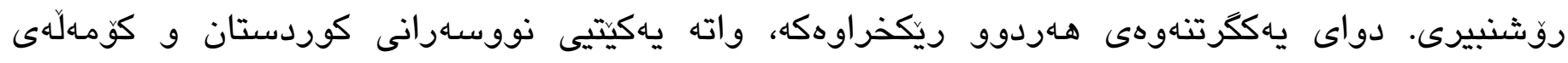

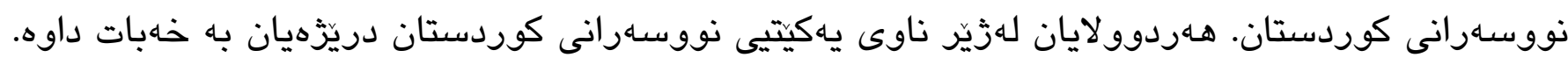




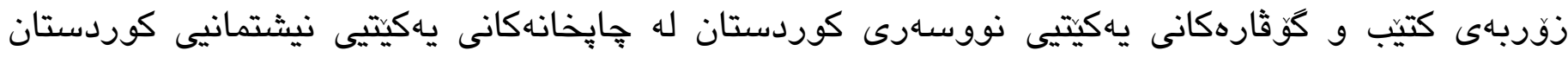

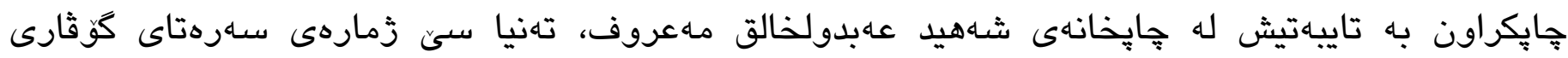

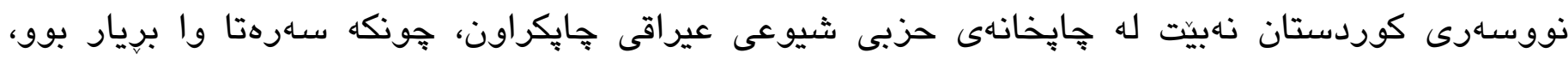

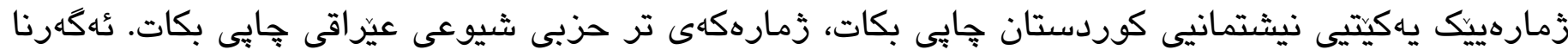

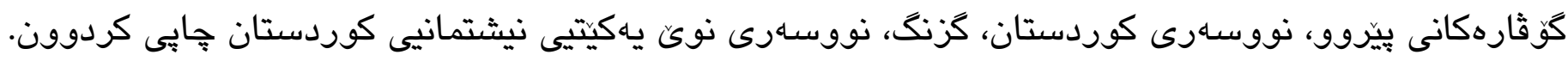
بو زانيارى زياتر جايخانهى شههيد عاهلدولخالق مـعروف، له لايهن يهكيتيى نيشتمانيى كوردستان بو يهكيتيى نووسـارانى كوردستانى دامـزرابوو، تهواوى يِيداويستييهكانى بو دابين دهكرد. له زوربهى زمارهكاندا ناوى دهستاهى نووسـران ياخود سـاهيهرشتيارانى كُوثارهكانى يـكيتيى نووسـاهرانى نهنووسراوه، بهلاّم له زمارهكانى

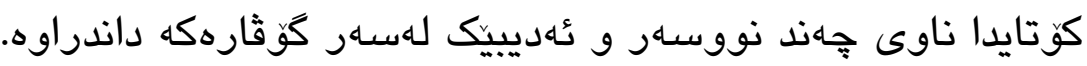

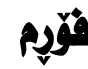

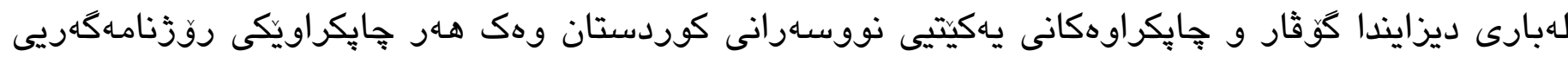

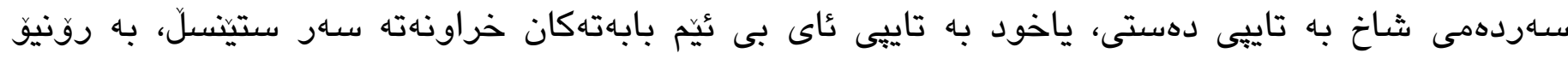

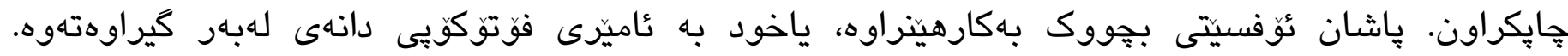

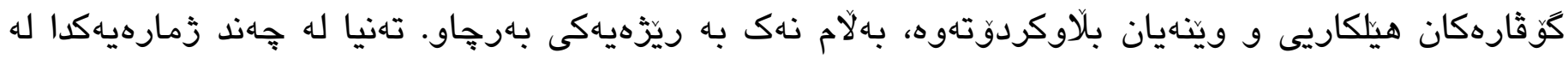
رهنكيَك زياتر بو جِايكردنهكهى بهكارهاتووه، به تايبهتيش له بهركدا. قهبارهيان زوّر جياواز نيه.

\section{كُمانج}

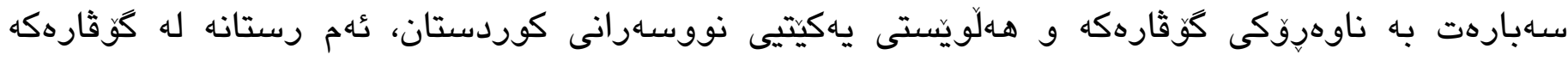
دهكوازينهوه "لهوهتهى يهكيتى نوسـاهانى كوردستان هاتوته كورىى خهبات و سهنكَهره ئهدهبيهكانى خوّى له

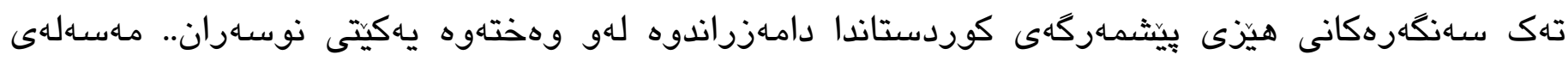

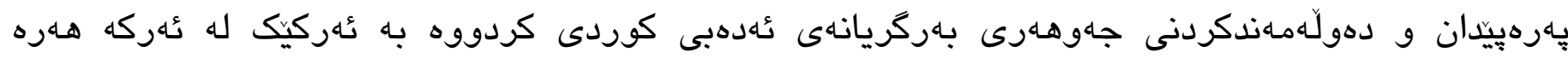

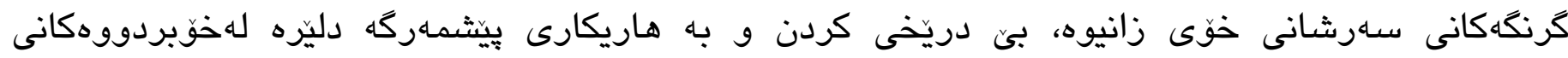

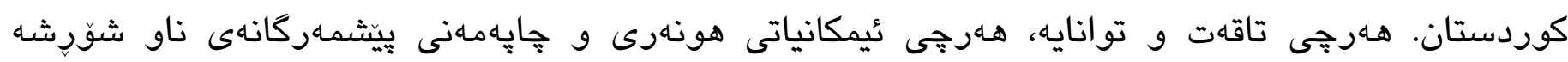

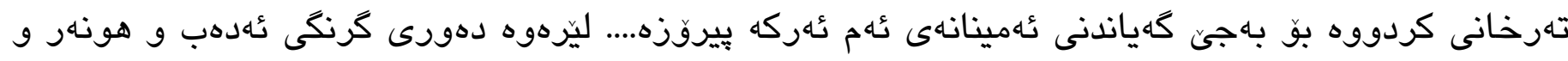

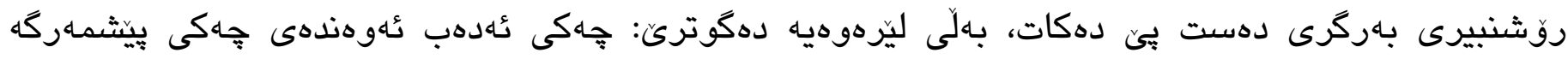

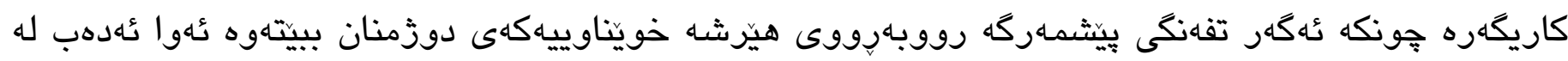




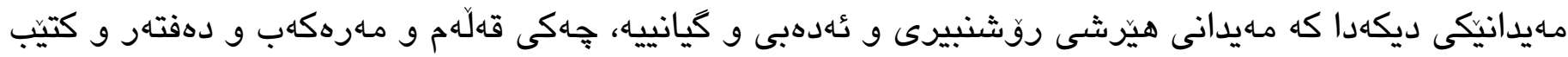

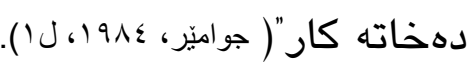
له كَّارهكانى يهكيتيى نووسـرانى كوردستاندا له جههندان زماره و بابهتدا، به تايبهتيش له وتهى زمارهدا باس

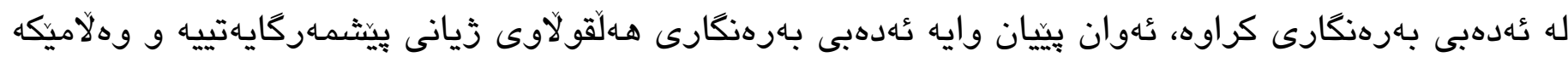
بو سياسهتى داكيركهرانى كوردستان دهرهـاق به مافه رهواكانى خهلك، له يهكيك له زمارهكاندا هاتووه "ئهدهبى

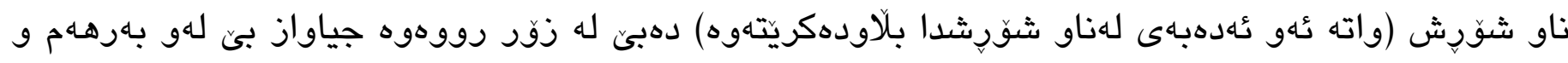

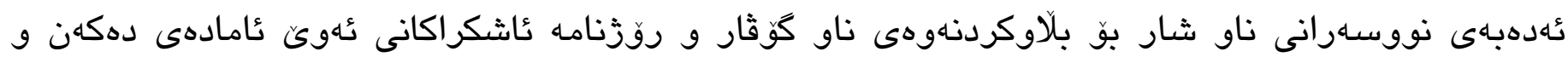

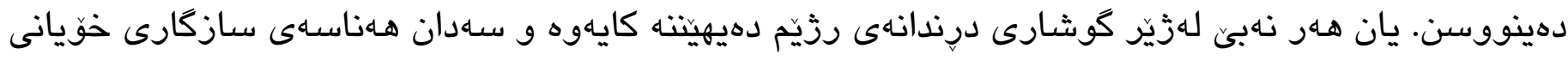

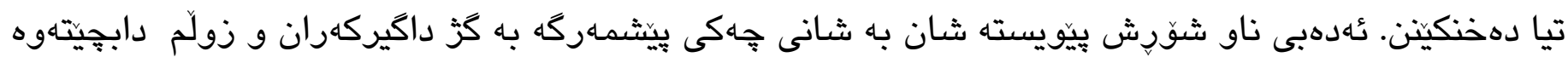

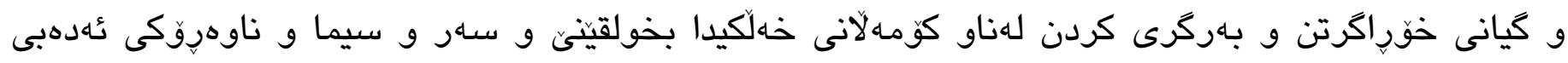

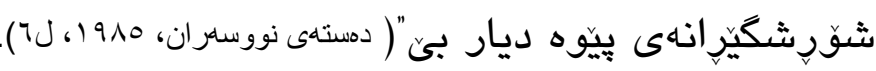

\section{ثناوهوِوكى}

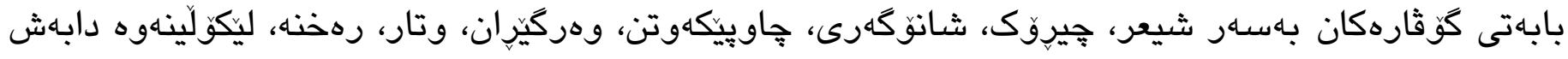

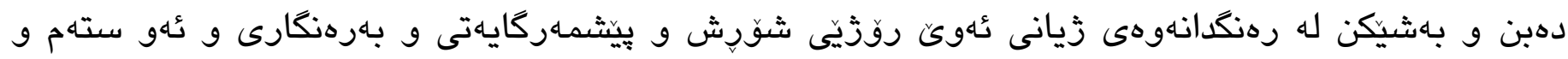
تاوانانهى كه داكيركهران دهرهـق بـ نهتهوهكهان يِيزِهويان دهكرد. بـه وردبوونهوه له بابهتهكان، كهواته كَّثارهكان كرنگيان به هـاموو هونهرهكانى ئهدهب داوه. هونهرى ئهدهب بهسهر شيعر و پِهشاندا دابهش

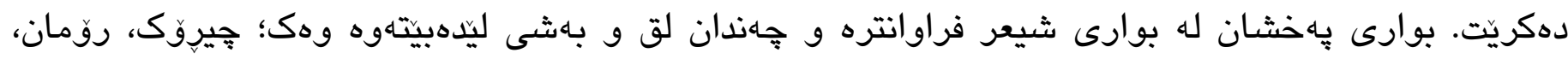

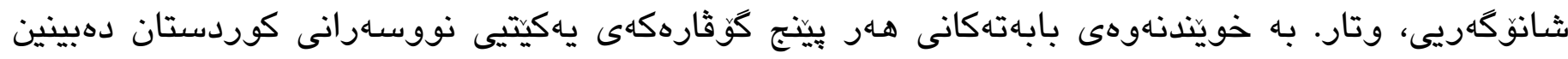

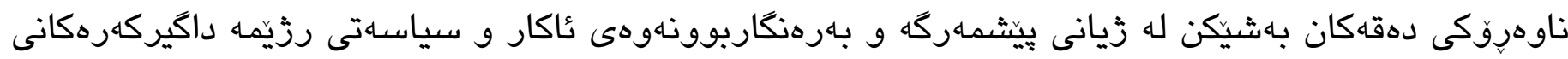

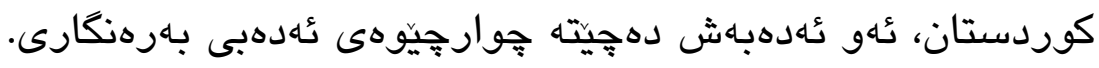

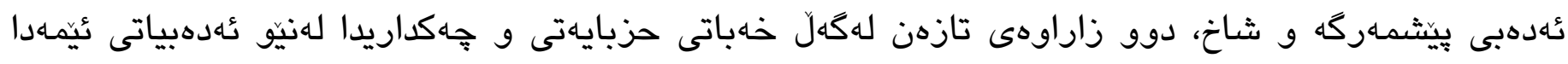

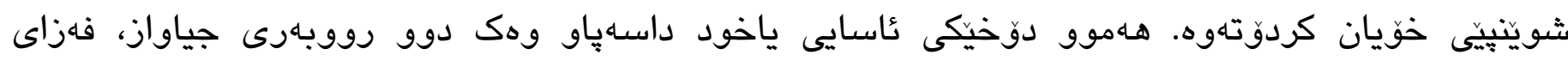

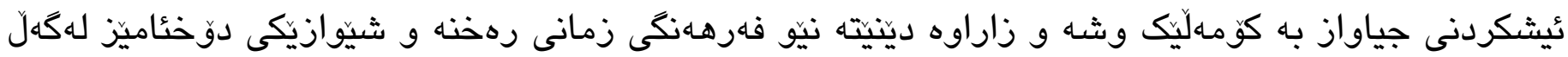

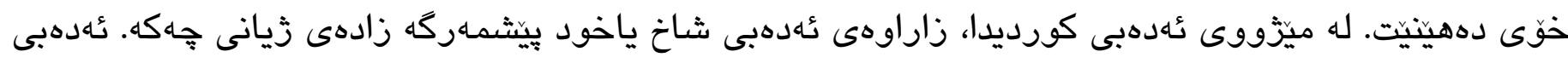

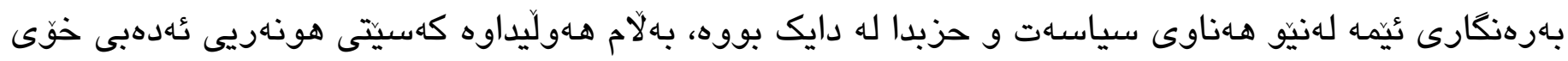
له دهست نهات!

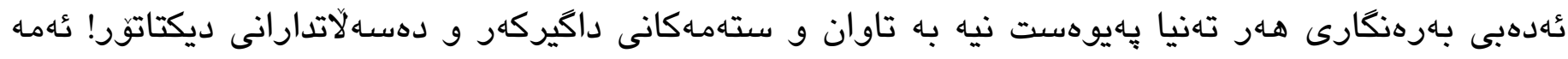

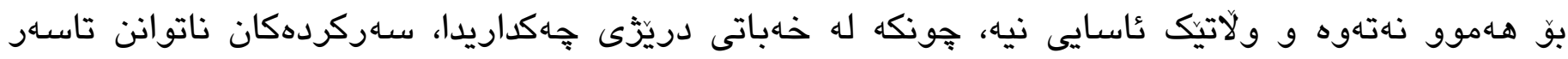




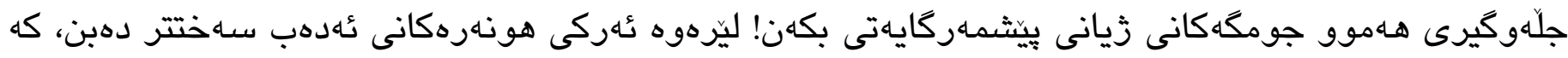
به تج كهرهستهيهك خهوش و كهموكورييهكانى زيانى يِيشمـهركايهتى بخاته جوارجيّوهى دهقهوه.

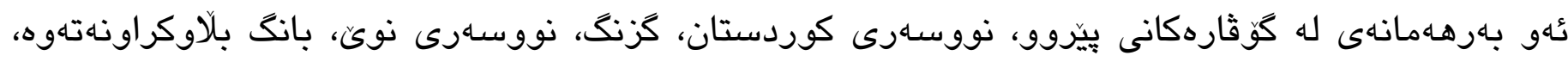

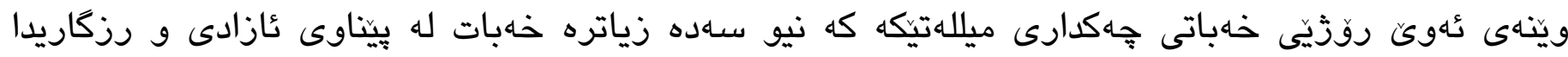

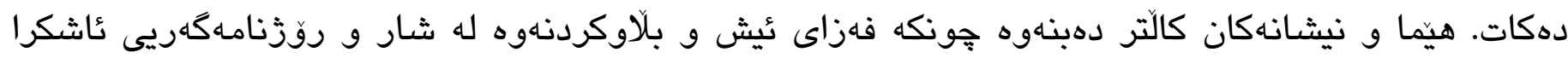

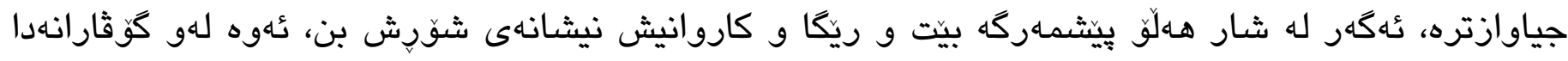

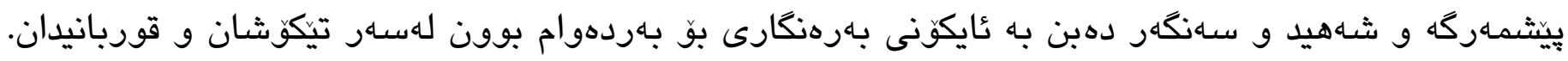

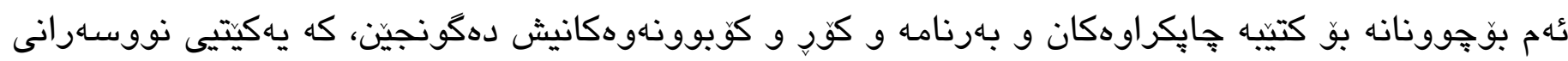
كوردستان بهريّوهيانى بردوون.

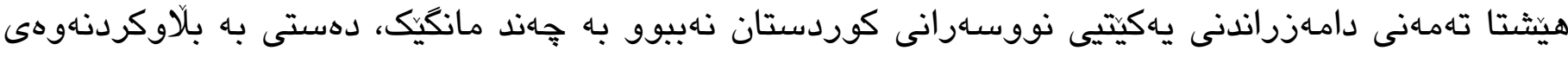

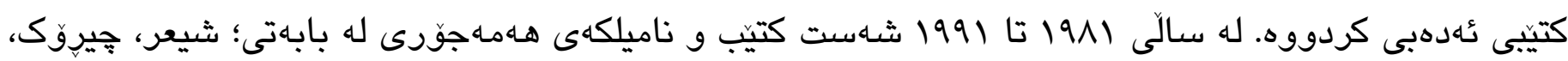

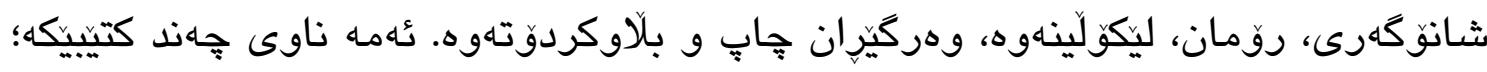
- رووباريكى خويناوى، شيعرى: شهاهيد جهميل رهنجبهر - ع س سهعات له خهو و بيّدارى، نووسينى: سهاهدىى بههرهنكى، و: رهفيق سابير 1911.

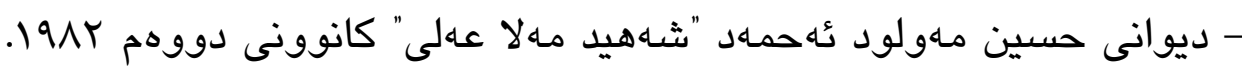
- يـكهمين ماموّستا، نووسينى: جهنكيز ئايتماتوقث، و: مستهاها غهفوور r 191.

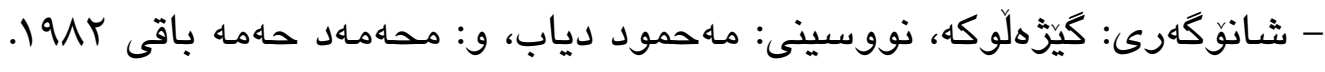

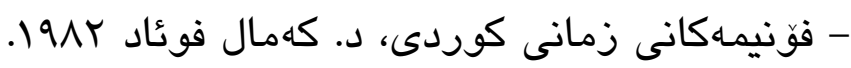

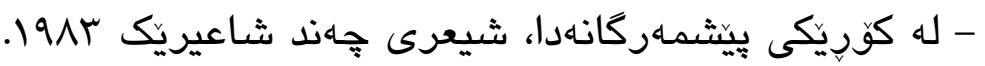

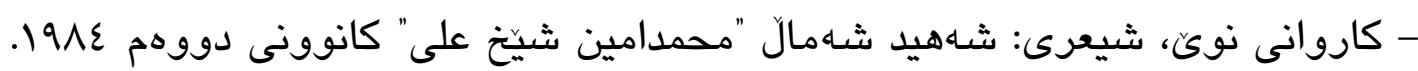

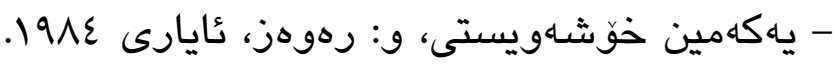

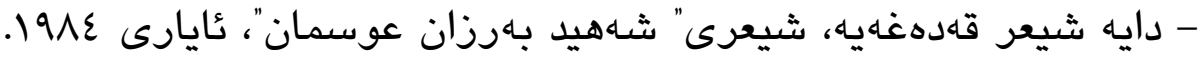

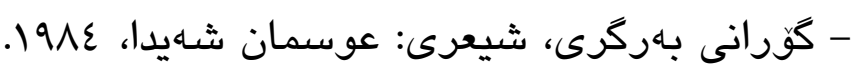

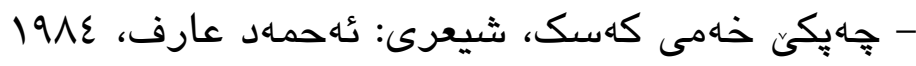

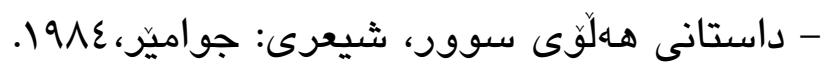

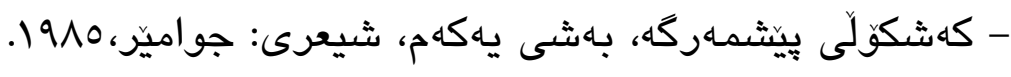
- هـرهس، رومان، محهمهد موكرى 1910. 


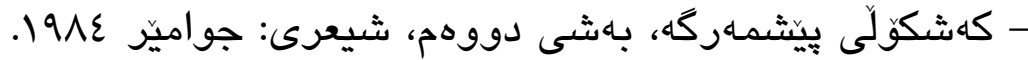

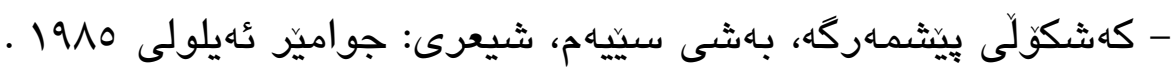

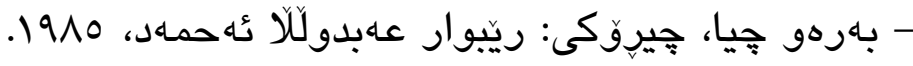

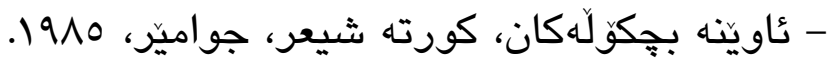
- كَرإنهوه بو حهيفا، نووسينى: غهسان كهنهفانى، و: عُهمهاد عارف، 1910. - يَإِينهوه، شيعرى: مـاهوجود سامان، 1917. - خاكى دايك، نووسينى: جهنگيز ئهتماتوف، رومان، و: زووان، 1917.

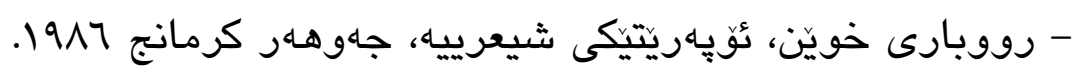

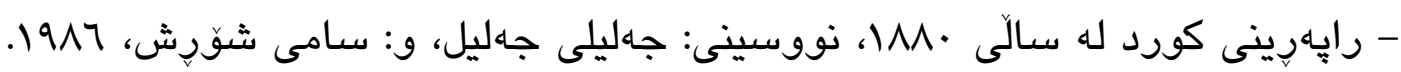

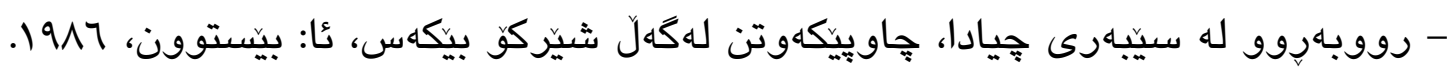
- تقلّله، رومان، محمد موكرى 1917. - يِيناسنامـكان، نووسينى: عهزيز نهسين، و: حهمهكهريم عارف

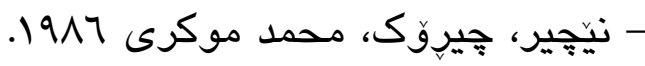

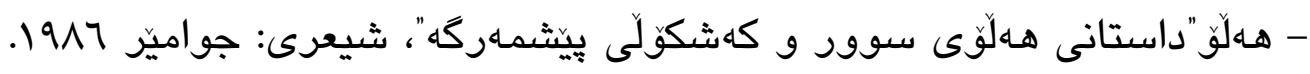

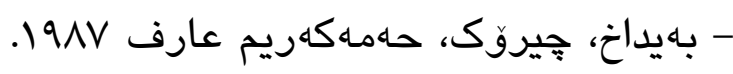
- تفهنگ، شيعرى: جهوهـر كرمانج 1911. - تهم توومان، شيعرى: شيّركق بيكهس، تايارى • 199.

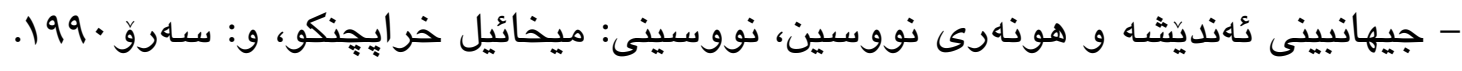

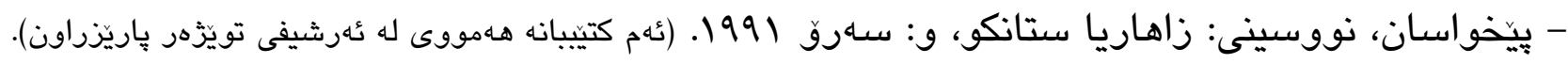

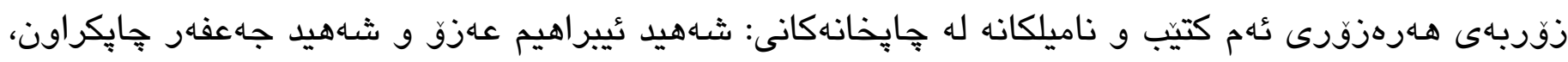

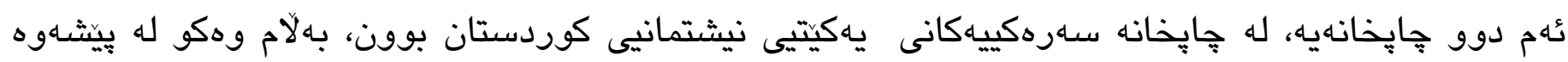

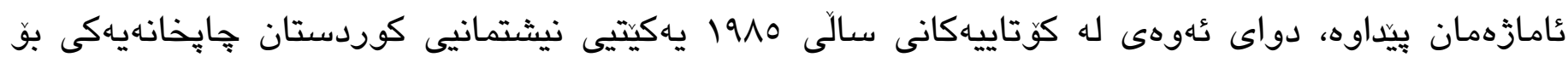
يهكيتيى نووسـهرانى كوردستان دابينكرد و ناوى لينزرا جإِخانهى شهاهيد عهبدولخالق مـهروف، كَّار و

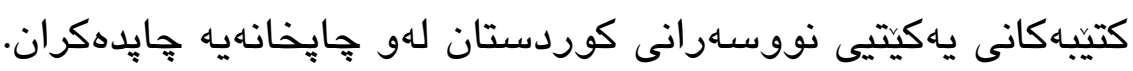

\section{* كوّر و كوَّبووثلهوه}

عُهندامانى يهكينيى نووسـرانى كوردستان روّليكى دياريان هـهووه له هاندان و يشتخيرى كردن له هالاكييهكانى

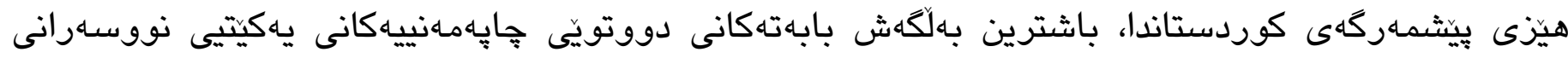

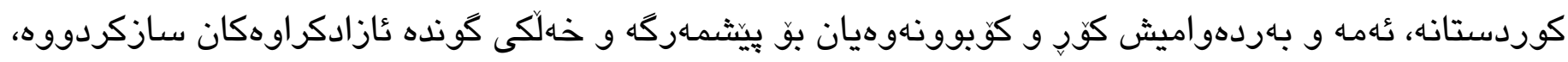

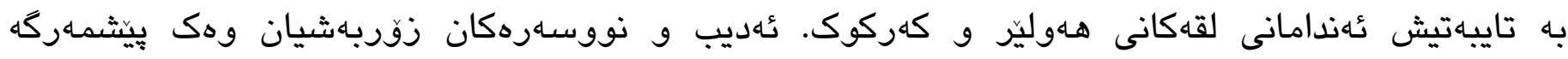




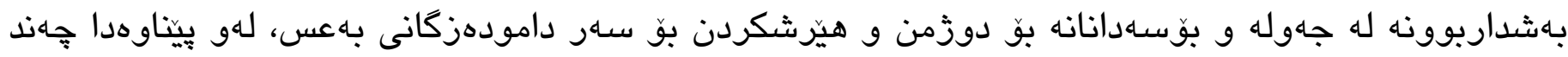
عُهنداميكى يهكيتيى نووسـرانى كوردستان وهك جهميل رهنجبهر، بهرزان عوسمان، شهامال"محهمهد تئمين"

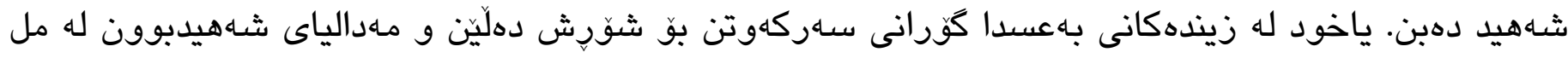
دهكهن، له يِيش هـهووياندا شهاهيد مـهلا عـلى.

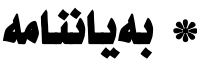

ياكيتيى نووسـارى كوردستان وهك ريكخراوينكى يِيشهيى، ثٔهركى نهتهوهيى و نيشتمانى خوّى رايهراندووه، جهاندان رووداوى نهخوازراو لهسـر كَّرهيانى كوردستان روويانداوه، به تايبهتيش پِهيوهندى ناتهندرووستى

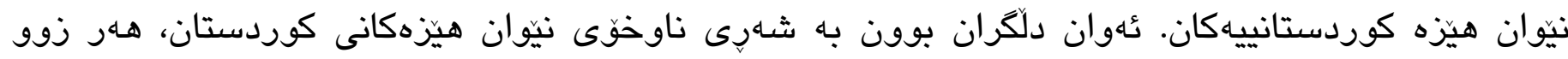

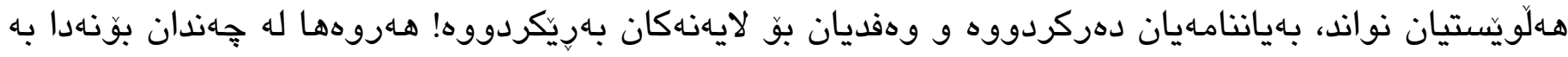

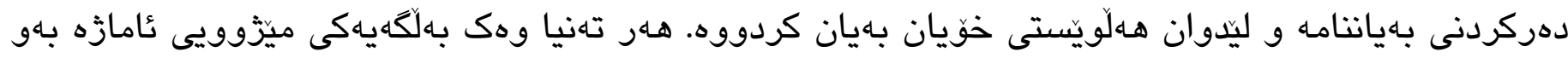

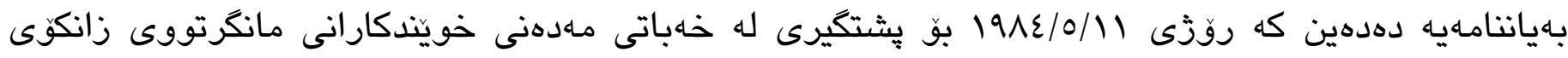
سهلاحهددين له هـوليّر دهريانكردووه، نووسيويانه: "وهك دهزانن مانكيك يتره خوينتكار دليّرهكانى زانكوىى

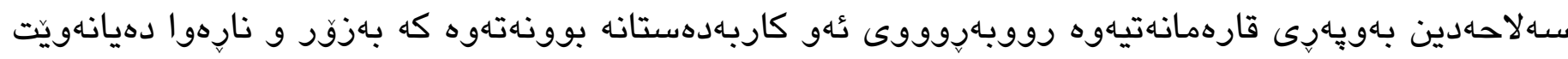
شتى لاوهكى و نارهوايان بهسهردا بساهيّنن و له خويندن و زانستيان دوور بخهنهوه. خويندكارهكانيش وهك

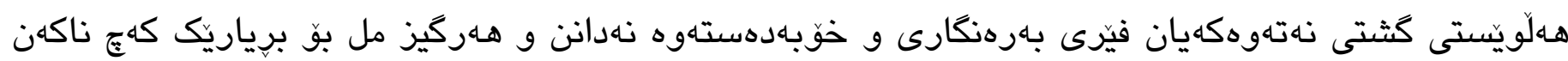

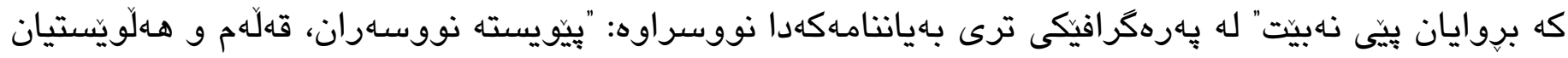

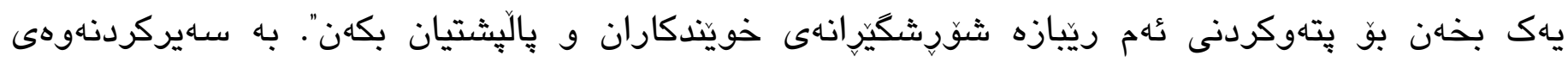
لإِهركانى كُّثارى نووسـهى كوردستان جههندان بهايانتامه دهبينين كه ريكخراوى ناوبراو دهريكردووه و له

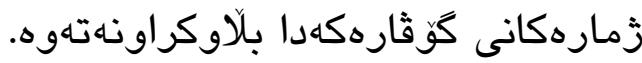

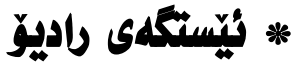

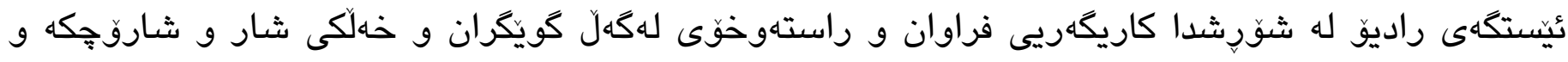

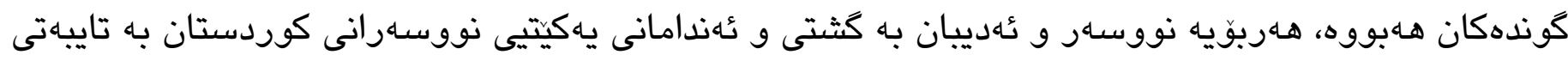

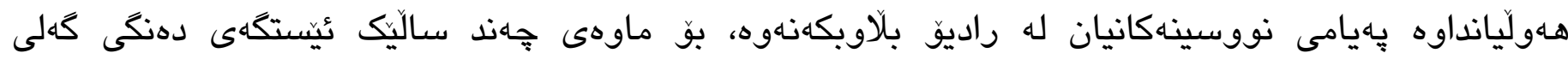

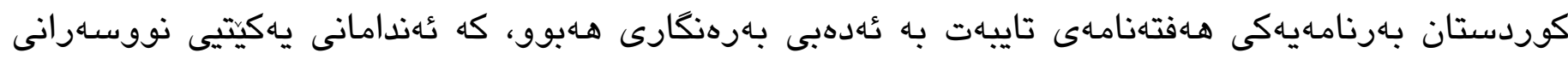
كوردستان ثامادهيان دهكرد و كهليك جاريش هـر خوّشيان بيّشكهشيان دهكرد. هـهروهها بهشداريان له نووسينى وتارى روذى ئيستكه و بوّنه نهتهوهيى و نيشتمانييهكاندا دهكرد، ثُهوان هاوكاريكى بهردهوامى بهرنامهكانى يُيستكَه بوون، به تايبهتيش له ئيستكَهى راديوى دهنكى كَهلى كوردستاندا. 


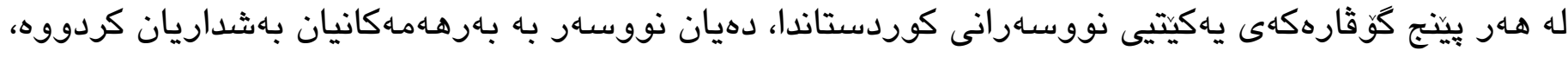

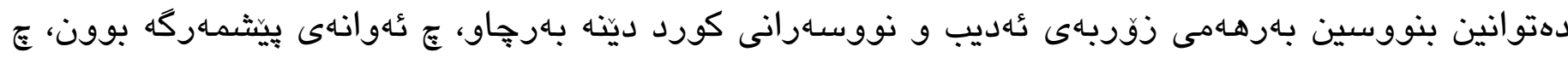

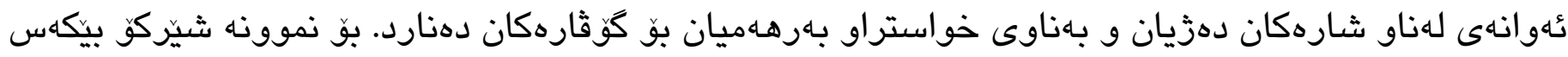

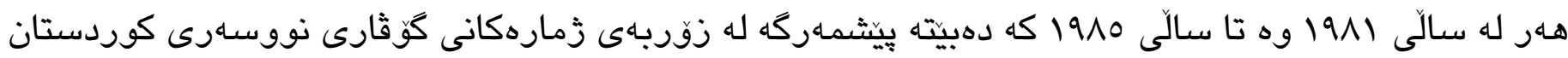
و كزنكدا بهناوى خواستراوى يِيروت ياخود جواميّر بهرهـهى هـهيه. بوّ زانيارى سـهارهت به ناوى نووسـهر و

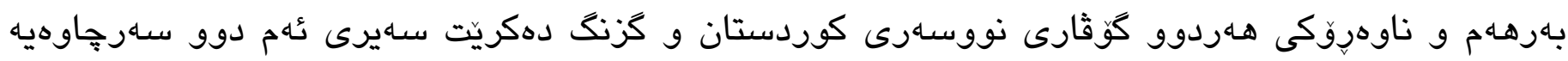

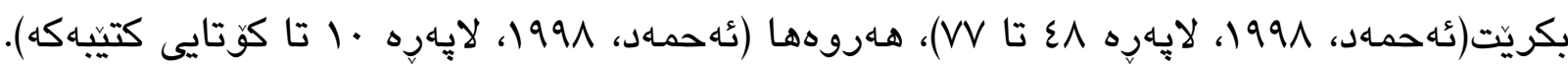

\section{!}

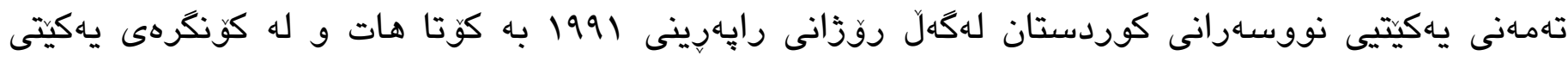

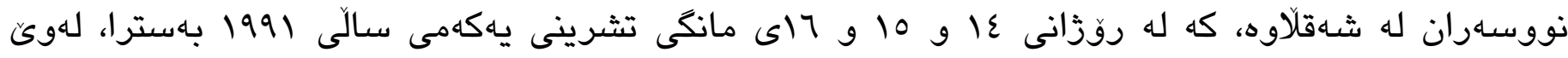
برياردرا نووسهران بكَريّنهوه سهر ناوه كوّنهك و لهزيّر ناوى يهكيتيى نووسهرانى كورد دهست به كار و جالاكييه كانيان بكهنهوه.

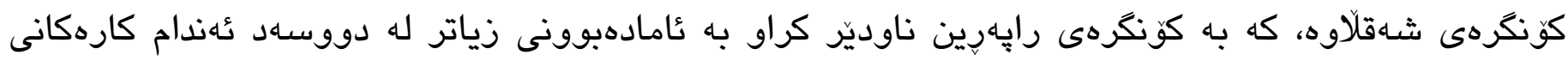

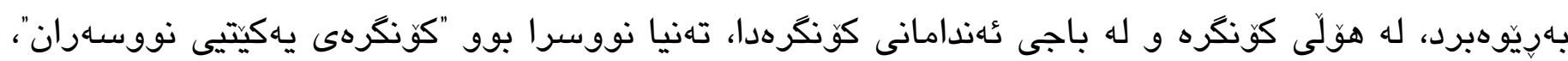

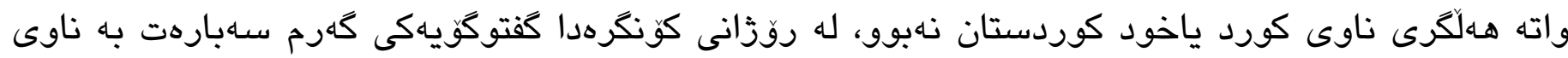
ريكخراوهكه كرا، بهلام له كوَتايدا بوّ ناوه كوَنهه واته يهكيتيى نووسـرانى كورد كهرانهوه، ئيتر يهكيتييهك نهما بهناوى ياكيتيى نووسـاهانى كوردستان، يهكيتيى نووساهرانى كورد زيندوو كرايهوه.

\section{ألهزجام}

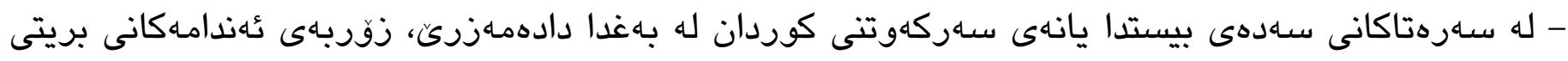
دهبن له نووسـر و ئهديبانى كورد، دهتوانين ئهو يانهيه ناو بنينين، يانهى ئهديب و نووسـرانى كورد.

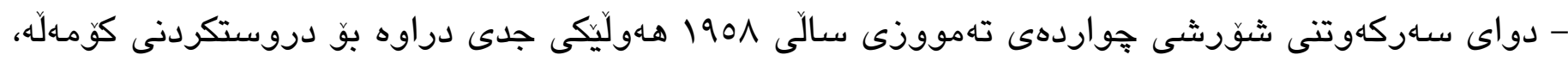

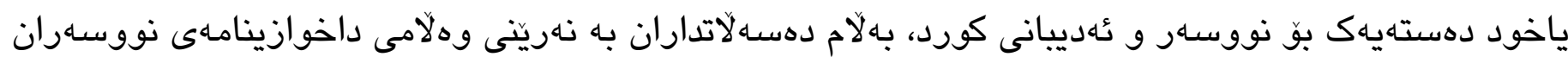

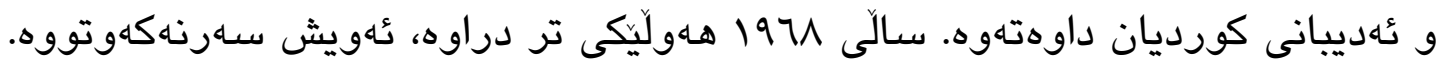

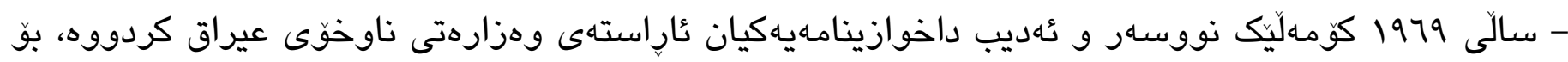
دامـزراندنى يهكيتييهك بوّ نووسهارانى كورد، سـهرهتا مهرجى ئهوهيان بوّ داناون، كه بين به ئهندام له يهكيتيى كُهديب و نووسـارانى عيراق، بـلاّم دوخيك هاتوته يِيشـاهوه ئهويش دانتان بووه بـه مافى روّشنبيريى كوردى و 
ئهوانيش سووديان لهو برياره وهركرتووه و وهزارهتى ناوخق دوزى • 1979/T/1 دان به يهكيتيى نووسارانى

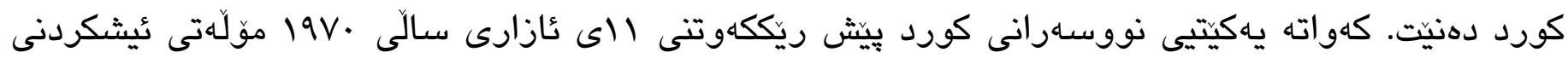

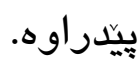

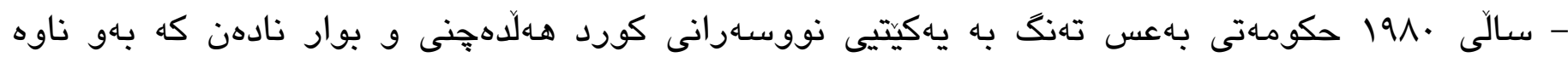
بهردهوام بن، فثـارهكان توندتر دهكرين، سالى ب19 19 دهركاى يهكيتيى نووسـهانى كورد دادهخيت و ريكخراويَك نامينيت بهناوى يه كيتيى نووسـاهرانى كورد.

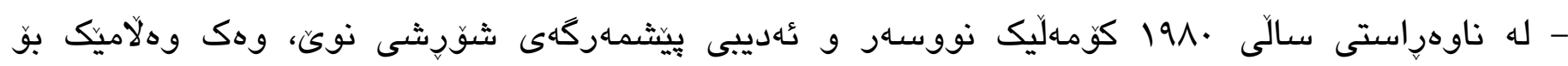

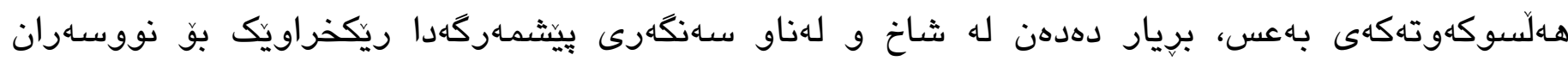

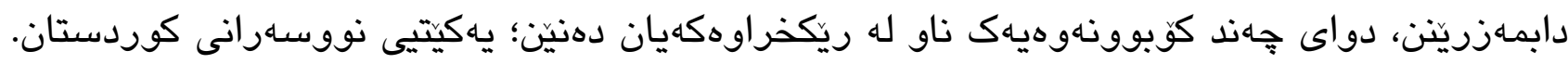

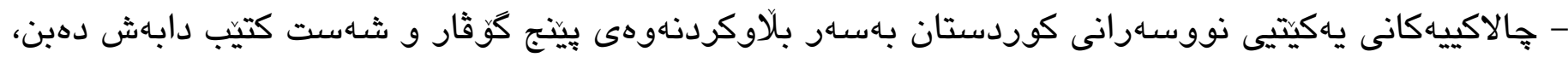

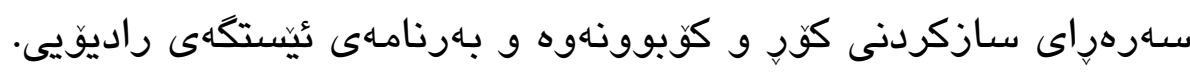

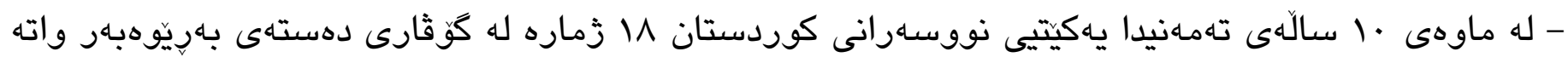

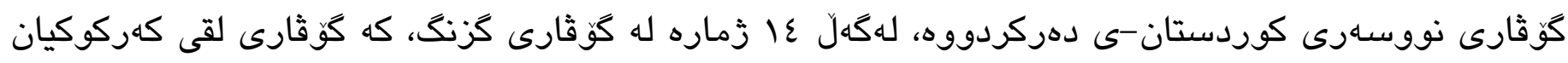

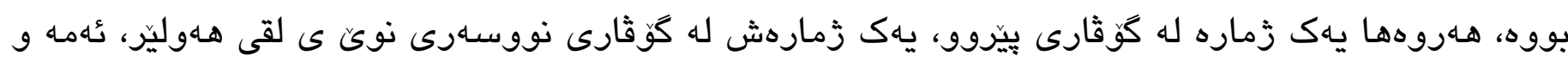
زماره يِينجى كُوثارى بانكَ-يش بهناوى يهكيتيى نووساهرانى كوردستان دهرجووه.

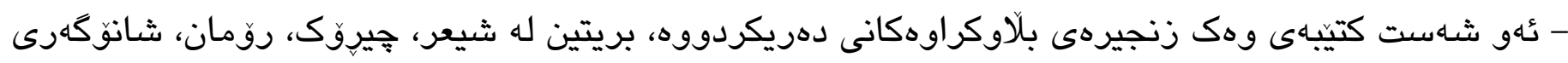

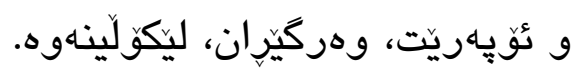

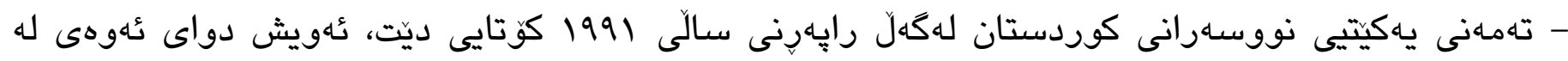

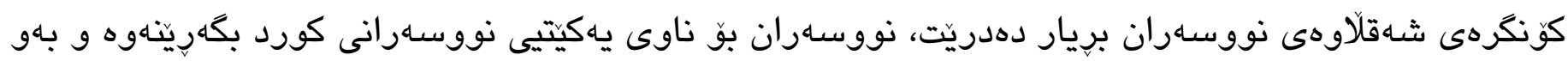
ثيّوهيه ريكخراوينك نامينيت بهناوى يهكيتيى نووسـارانى كوردستان. 


\title{
Kurdistan Writers' Union Its Foundation, Activities and Dissolution
}

\section{Dilshad Ali Muhammed}

Department of Kurdish Language, College of Languages, University of Sulaimani, Sulaimani,Kurdistan Region, Iraq.

E-mail: dr.dilshad52@gmail.com

\section{Nawzad Ali Ahmed}

Department of Kurdish Language, College of Languages, University of Sulaimani, Sulaimani,Kurdistan Region, Iraq.

E-mail: Nawzad.ali@hotmail.com

\begin{abstract}
:
The ceasefire between the Kurdistan Democratic Party-Iraq and the Baathist government in 1974 came to an end, and fighting between the two sides resumed. The war lasted another eleven months. At the start of the war, a group of writers and artists reached out to areas controlled by the revolution and formed organizations. Many of them were members of the Kurdish Writers' Union and They were able to issue 12 of their magazine, but the writers' union was established in Baghdad, not in the revolution. After the collapse of 1975 and the resumption of the new revolution in the areas under Peshmerga control, especially in the early 1980s, for the first time in the battlefields of resistance and defense in Kurdistan, a special organization for writers and writers was established, called the Kurdistan Writers' Union..

The Kurdistan Writers' Union's establishment and activities were addressed in this study, and the reason for its cancellation was clarified. The first section of the study, which was split into two sections, focused on the efficiency and explanations for the organization's formation. The publication chosen by the Kurdistan Writers' Union through a series of criteria is the subject of the second part of the study.
\end{abstract}

Keywords: Kurdistan, Writers Union, Dissolution, Revolution. 
كُهرسهلان بايز ئيسماعيل، راكهياندنى شوّرش و بزووتنهوهى شيعرى كوردى، جإِخانهى روون، سليمانى I..T.

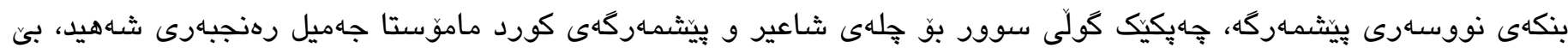
جايخانه ·

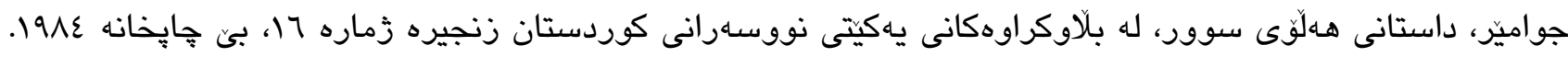

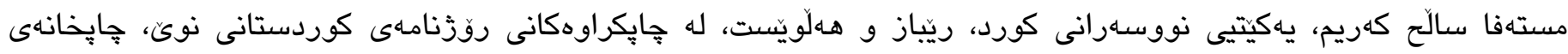

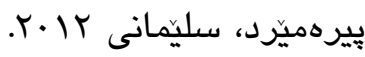

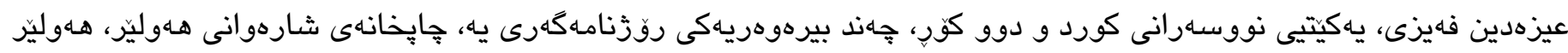
.1911 نهوزاد عهلى ئهمهاد، ياسين قادر بهرزنجى، بييليوكرافياى هـردوو كَّقارى نووسهرى كورد و نووسهرى كوردستان، يِيشهكى:

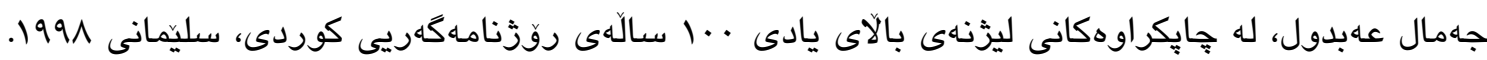

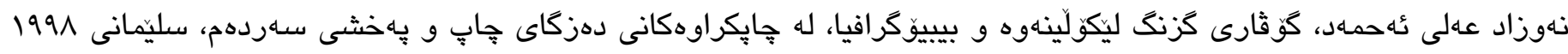

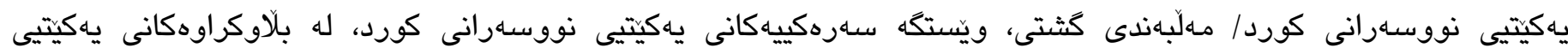

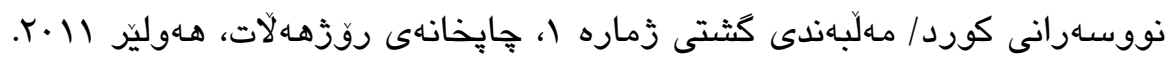

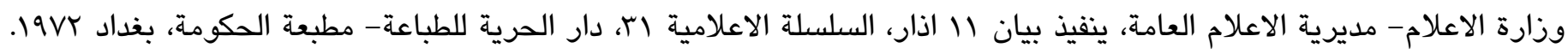

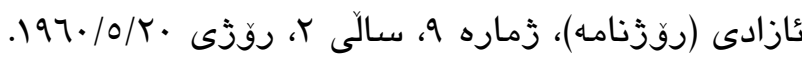

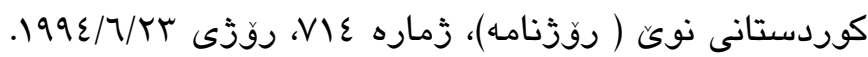
نووسهرى كوردستان(كُّار) هـهوو زمارهكان ا تا 11، سالّى 1911 تا 1991.

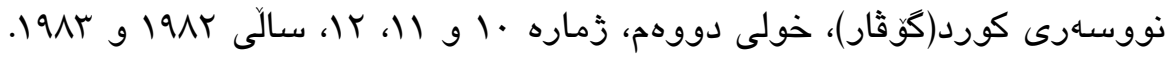

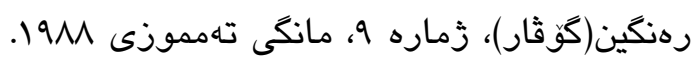
الشفق(مجلة)، العدد 7، 0، المجلد ، كركوك، مارس و حزيران 1901. هنا صوت كوردستان(نشرة)، ب اعداد، عVI9. 